\title{
An Assessment Of The Performance Of The Cameroon Water Corporation For The Period 1967 To 2013
}

Saidou Baba Oumar, University of KwaZulu-Natal, South Africa Josue Mbonigaba, University of KwaZulu-Natal, South Africa

\begin{abstract}
This paper assesses the performance of the Cameroon Water Corporation $(C W C)$ in delivering services after four decades of existence (1967-2013) and relates that performance to organization theories. It uses secondary data on services provision and primary data on users' perceptions of the CWC's performance. The assessment is conducted using descriptive as well as inferential methods of data analysis. The paper observes that despite political, technical, managerial, and financial constraints that impaired the efficient delivery of drinking water and sanitation services in the country over the years, the company registered modest successes that attracted the financial support of domestic and worldwide development partners. However, more than half of the population is sceptical about better future services delivery by the CWC. Classical organization theory (COT) explains most of the failure in the operating environment of the $C W C$, while the formulations in modern organization theory (MOT) are found to be relevant to the improvement of water services. As a policy recommendation, the CWC should focus on MOT, while maintaining some aspects of COT to improve performance.
\end{abstract}

Keywords: Drinking Water; Sanitation; Management; Organization; Cameroon

\section{INTRODUCTION AND OBJECTIVES}

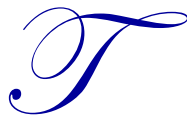

he concept of organization denotes different things to different people. To some, it represents a place for making money, a context for socialization, and a laboratory for exercising power and control. To others, it symbolizes a site for open and hidden conflict between people and positions, and a forum through which the mechanisms for transforming society and enhancing living conditions of people are applied. It is in the context of these different images of organization, that this paper assesses the performance of the CWC, known as Société Nationale des Eaux du Cameroun (SNEC), set up by the Government of Cameroon (GC) in 1967 to provide drinking water and sanitation to the Cameroonian population.

Generally, organizations succeed or fail due to their ability or inability to respond to changes in the business environment, accommodate new realities, condone partiality in administration, decentralize power, and humanize authority. Therefore, the performance of an organization, such as the CWC, hinges on the extent of its accommodation of socio-politico-economic and environmental factors. The literature highlights that socio-politicoeconomic factors such as miscommunication, lack of evaluation, resistance to innovation, and lack of learning can lead to the dysfunction of an organization and therefore affect its performance (Walkup, 1997). Thus, the main objective of this paper is to assess the performance of the CWC towards meeting its commitments from 1967 to 2013, and relate its performance to organization theories (OTs) by linking socio-politico-economic factors to performance, in a bid to find the theoretical frameworks within which the CWC can perform better. Other specific objectives of the paper include:

- $\quad$ To review the mechanisms and practices by which the corporation functions;

- $\quad$ To explore the achievements, constraints, prospects of the corporation;

- To assess the judgment of consumers on the future performance of the corporation; and

- To recommend better delivery of drinking water and sanitation services in the country. 
The remainder of the paper is organized as follows. Section 2 reviews OTs. Section 3 explains the methodology. Section 4 focuses on the results and discussion, while Section 5 concludes and outlines policy implications.

\section{REVIEW OF ORGANIZATION THEORIES}

The elusiveness of the concept of organization justifies the plethora of OTs, each with its own perspective, attempting to explain the driving forces behind the effectiveness, efficiency, growth, inefficiency, and downfall of organizations. Diversity in theorizing organizations is due to the fact that organizations operate in diverse environments under different conditions, consist of people with contrasting backgrounds and interior motives, and are managed by people with different perceptions and visions of them. This complexity of organization can be discussed in terms of three main schools of thought, notably, COT, neo-classical organization theory (NCOT), and MOT. A short account of these theories follows.

COT, originating in the field of commerce, holds that organizations should focus attention on production and economic objectives through systematic and scientific inquiry based on the division of labor and specialization, to create an efficient system in which workers serve as substitutes for mechanical parts of the industry apparatus at any time. From this perspective, the proper functioning of a formal organization is one of well-designed and coordinated mechanical relations between the various means of production, namely, machines, money and of course people, with little care given to people who work for the health and growth of that organization.

In COT, performance (increase in production, efficiency, or saving time) is achieved either through separating stages in the production process (Smith, 1776) by applying bureaucratic rules governing performance (Weber, 1922, 1947), or by improved planning, coordination, and commanding of activities of the organization by managers (Fayol, 1949). COT is credited with the ability to narrow its scope by focusing on economic-related goals to improve production, and addressing and furthering organizational functions using methodical and rigorous investigation at a time when little means were available. Further, it remains highly influential in today's trading activities. Yet, this articulate theory is too restricted to production, undermines the human component, ignores environmental factors and fails to reflect all organizational realities of the world. It is from these criticisms that NCOT arose.

NCOT focused on the concerns of humanness rather than on the mechanical understanding of organizations of the COT thinkers. NCOT explains that the performance of an organization depends on humanness, coherence among managerial sections of an organization, and good operational relations within and outside the organization. It upholds that organizations cannot exist as independent islands that are isolated from the environs in which they operate. Thinkers in this school indicate that performance of an organization results from interdependent relations between groups of individuals in a bureaucracy (Merton, 1940), from the preparedness of members of an organization to cooperate (Barnard, 1938), and from the setting up of a cooperative social system where conflict between personal and organizational goals can be resolved (Selznick, 1948). It is important to note, however, that throughout its era, NCOT neither implemented an empirical investigation nor developed a theoretical base to support its claims to adequately serve as a substitute for COT. Thus, many critics regard it as an anti-school because of its inability to stand alone as a school of thought with its own assumptions and principles. This major deficiency triggered the advent of MOT.

Within MOT, both the production efficiency criterion of COT and the human-centered concerns of NCOT are considered to be factors relevant to the performance of an organization. In particular, MOT explores a number of theories concerned with humanity that were not developed within NCOT. Such theories are human resources theory (HRT) or organizational behavior theory (OBT), workplace external environment theory (WEET) or modern structural theory (MST), culture and change in organization theory (CCOT), ownership of information theory (OIT) or organizational economics theory (OET), pressure group theory (PGT) or organizations and environments theory (OsEsT), and power and politics organization theory (PPOT).

HRT explains how caring for employees can lead to improving the performance of organizations. Mayo (1993) indicates that listening to workers as humans, allowing people to control their own work, and acknowledging different needs will motivate people to be more productive. Maslow $(1943,1954)$ argues that organizations that help 
employees attain self-fulfillment and respect, achieve better performance levels as employees become more motivated to perform their duties well. Further, McGregor (1960) contends that workers can be work averse and need to be stimulated (theory X), while on the other hand, workers may love their work as long as the job matches their aspirations (theory Y). These theories posit that a poor relationship between an individual and the organization generates suffering for both individuals and organization, as maltreated individuals would not seek to satisfy the goals of that organization. Briefly, all these theories reject the idea that the employee depends on the organization or the organization depends on the employee, but subscribe to the idea of interdependence between the two entities.

While HRT highlights employee concerns as crucial to the performance of an organization, MST stresses the environment of organizations. MST maintains that whether formal or informal, the context within which organizations operate represents the crucial factor in achieving success. Burns and Stalker (1961) posit that the performance of an organization in a specific context depends on whether the organization is formal or informal. Blau and Scott (1962) postulate that formal organization is not the only suitable form of organizing activities, suggesting that the formality or not of an organization is not a precondition to better performance in a given context. Walker and Lorsch (1968) advocate that the performance of an organization depends on its transformation to suit the environment in which it operates. Briefly, this theory posits that formal authority and the external environs of the organization are important for its performance. It, however, fails to take into account the power of outside influences.

While MST focuses on an organization's environment as a crucial factor in its performance, CCOT focuses on the culture of an organization as key to performance. The performance depends on the extent to which organizational culture, such as morals, dogmas, expectations, and organizational practices adapts to the needs of the organization. In this perspective, Jacques (1951) considers managerial hierarchy as the only way to construct integrated working systems with many thousands of workers in an organization. Along the same line of ideas, Schein (2004) highlights that the understanding of culture by managers is important, since they can be aware of its effect on the performance of an organization and strategize accordingly. Cooperrider et al. (2008) advocate a culture of appreciation to transform ideas that reflect inflexibility, uniformity, and overreliance on procedures as key to the performance of an organization. Briefly, the CCOT blends human relations aspects with ideas from other schools of thought to produce a vast body of instruments that can be used in implementing organizational change. Yet, it is too focused on external environments and not rational in its approach as culture and symbolism are hard to identify, hence the impracticability of introducing changes based on such variables.

Another theory within MOT is OET. This theory focuses on economic aspects of organizations, such as transaction costs, role of an agent, pricing of goods and services, contract of services, strategy of producers, and ownership of property rights. In this perspective, Williamson (1975) explains that hierarchical sub-components are the key to checking transaction costs by way of exchange relationships between the components of an organization. This economic interdependence is also highlighted by Ouchi (1981) who contends that an organization's performance relies on other organizations. Lastly, Pfeffer and Salancik (2003) maintain that all organizations exchange resources within their surroundings as a condition for survival. This view alludes to the difficulty of comprehending the construction and behavior of an organization without exploring the economic framework within which it functions. Thus, the key to organizational survival is the capacity to secure and sustain scarce environmental resources. Even so, this theory is a nightmare for non-experts due to its use of sophisticated economic concepts and its emphasis on moral considerations.

Related to OET is OsEsT, which upholds that interdependence is an important aspect in an organization. With OsEsT, the performance of an organization depends on the extent of its exchange with the outside environment. From this angle, Wiener (1948) maintains that an organization is a system of interdependent activities implanted in and reliant on broader environments, and its performance is related to how it works. Besides, Meyer and Rowan (1977) emphasize that it is the cultural and institutional environment that influences the performance of an organization. Likewise, Carroll and Hannan (2000) proclaim that the environment selects the fittest among different organizational forms through the processes of founding, growth, decline, transformation, and mortality. Yet, the focus of control of this theory is mostly external with little consideration of the closed systems. 
Finally, PPOT explains that the performance of an organization can depend on the arrangement to get hold of limited resources in organizations by connecting to people with power in the organization. In view of that, March (1966) is of the opinion that power is not limited to power inside organizations and concludes that although power and influence are useful towards achieving performance, they do not always explain organizational choices. Besides, Mintzberg (1992) argues that organizational behavior is comparable to a power game. The players are influencers with varying personal needs who attempt to control organizational decisions and actions. Thus, to understand the behavior of an organization, it is necessary to understand which influencers are present, what needs each seeks to fulfill in the organization, and how each is able to exercise power to fulfill them. To sum up, Pfeffer (1994) regards power as a structural phenomenon resulting from division of labor and specialization. Thus, it is described as the aptitude to get things done in a specific manner.

With the introduction of an aspect of power and politics to organizational function and behavior, PPOT attempts to identify all aspects of and players with political power and influence in institutions. Although this strand created a consciousness of the incessant competition between the components of organizations, it provides no solution to the problem. Moreover, it offers no concrete way on how to enhance the protection of people and their institutions from the authority of power and politics.

To recapitulate, this section discusses three main schools of theories of organization, notably COT, NCOT, and MOT as they relate to the performance of an organization. COT emphasizes a high level of specialization, rigid hierarchy of authority, centralized organizational power, and narrow scope of control. NCOT stresses the role of individuals and environmental contexts, while MOT blends aspects of both COT and NCOT (Docherty et al., 2001). The next section explains the methodology.

\section{METHODOLOGY}

This section discusses the methodology of the study. It provides a description of the study area. It also expounds the materials and methods used in analyzing the phenomenon under examination.

\subsection{Study Area}

Cameroon is a lower-middle-income country. Its gross national income per capita (GNIPC), based on the 2011 World Bank's classification of economies of the world, is US\$1210 (World Bank, 2013). The country is located in Central Africa between latitudes $2^{\circ}$ and $13^{\circ}$ north of the equator and longitudes $8^{\circ}$ and $16^{\circ}$ east of the Greenwich Meridian of the globe, with a total land mass of $475650 \mathrm{Km}^{2}$, and shares its boundary with Nigeria to the west, Central African Republic and Chad to the east, Equatorial Guinea, Gabon, and Congo to the south, and a small portion of Lake Chad to the north (National Institute of Statistics [NIS], 2006, p. 2). Cameroon is administered through 10 regions (NIS, 2006), with English and French as the official languages in addition to the over 250 other languages spoken by the 19.4 million people in the country in 2010 (African Development Bank [AfDB], 2010, p. 13). The seasons of the year are split into two: a dry season running from November to June, and a rainy season spanning July to October in the northern part, and a dry season extending from January to March and a wet season lasting from April to December in the southern part of the country. On average, the country has $1600 \mathrm{~mm}$ of rainfall per annum (NIS, 2006), with 5 drainage basins, including the Atlantic, Congo, and Sanaga basins in the south and Niger and Chad basins in the north, containing many rivers and lakes. Molua and Lambi (2006), Neba (1999), and Encylopaedia Britannica (2010) observe that the main rivers in the country include the Sanaga (918Km), Nyong $(800 \mathrm{Km})$, Ntem $(400 \mathrm{Km})$, Wouri $(250 \mathrm{Km})$, Benue $(1400 \mathrm{Km}$ but $350 \mathrm{Km}$ in Cameroon), and Logone $(390 \mathrm{Km})$, while the major lakes are Baleng (Bafoussam), Ejagham (Mamfe), Ossa (Edea), Bamenjim (Ndop), Mbakaou (Tibati), Chad (Makary), Maga (Maga), Nyos (Isu/Fundong), and Lagdo (Lagdo).

\subsection{Materials and Methods}

This paper uses two types of data to assess the performance of the CWC, using both secondary and primary data. Secondary data, collected from reports of the Republic of Cameroon (RC), National Institute of Statistics (NIS), World Bank (WB), National Archives, Buea, Cameroon (NABC), newspapers, and CWC were used to assess the performance with respect to the functional mechanisms and practices of the $\mathrm{CWC}$, and with respect to its 
achievements, constraints, and prospects. In particular, the study assessed the implications of management structure, costs of connection, pricing, and tax disparity. Each implication is associated with an OT that most relates to that finding. Secondary data were analyzed mainly using descriptive statistics, notably diagrams, tables, and percentages.

In addition, the assessment used data on the perception of people of services delivery by the CWC. The primary data were generated through questionnaires, interviews, and personal observations. A purposive random sampling technique was employed to generate the required information from a cross-section of the population in Buea and surrounding areas in Cameroon. In the process of data collection, 78 questionnaires were distributed to people out of which $68(87.17 \%)$ were completed and returned to the researcher, and 42 other individuals were interviewed, thus making a sample size of 110 respondents whose points of view were used to assess the ability of the CWC to deliver adequate drinking water and sanitation to the people. The analysis of the data is expected to synthesize the views on the future performance of the corporation.

Primary data were analyzed using both descriptive and inferential types of analysis. The descriptive technique involved the use of diagrams, tables, and percentages; whereas the inferential technique employed the Chi-square $\left(\chi^{2}\right)$ statistic under six individual scenarios focusing on demographic characteristics such as the gender, marital status, age group, level of education, profession, and residential area of the respondents, respectively, and one aggregate model that embodies all of the demographic characteristics of the respondents as a set to test the extent to which these variables influence people's judgment on the ability and future performance of the CWC. In each case, only the null hypothesis is stated for investigation to avoid redundancy in the text. Table 1 recapitulates the discussion in brief and the results of this analysis are discussed next.

Table 1: Instruments, Sample Elements, and Return Rate of Field Survey

\begin{tabular}{lccc}
\hline \multicolumn{1}{c}{ Instrument } & Targeted Population & Respondents & Percentage (\%) Return \\
\hline Questionnaire & 78 & 68 & 87.17 \\
Interview & 42 & 42 & 100 \\
Total & 120 & 110 & - \\
\hline Source: Authors & & &
\end{tabular}

Source: Authors

\section{RESULTS AND DISCUSSION}

This section elaborates on the findings of the study. It examines the specific objectives by addressing issues ranging from the functioning and practices of the CWC through to its achievements, constraints, and prospects, and the judgment of people on the ability of the corporation to adequately deliver drinking water and sanitation services to them in future.

\subsection{Functioning Devices and Practices}

The examination of the functioning and practices of the corporation emphasizes the various operational aspects of the corporation. These concern the management, costs of connection, water charges, and tax disparities of the corporation.

Structure: A four-level hierarchy runs the day-to-day activities of the CWC. At the top level, the managing director (MD) oversees all activities of the company. The second level consists of a deputy managing director (DMD) to assist the MD. The third level comprises directors of works and maintenance, commercial affairs, quality assurance, exploitation, purchases and logistics, finance, legal matters, and human resources of the company. The fourth level is made of eight regional office delegates who assist in implementing the decisions of the company in their respective area of command. These delegates head the North office in Garoua, East office in Bertoua, Central office in Yaoundé, South office in Ebolowa, Littoral office in Douala, West office in Bafoussam, Southwest office in Buea, and Northwest office in Bamenda. The CWC observes a rigid order of hierarchy in the decision-making process. The giving of orders and taking of decisions strictly run from the MD to the bottom level of the company with no possible digression between offices. Each subordinate office is expected to channel its needs and grievances to its immediate superior in the hierarchy in the order of 4 to 3,3 to 2 , and 2 to 1 , respectively, as shown by the discontinued arrows in Figure 1. Thus, it is impossible to image regular official communications between the 
directors and MD, regional delegates and MD, or regional delegates and DMD, as shown by the interrupted arrows in Figure 1. A careful examination of the structure of the CWC reveals the presence of a highly inflexible hierarchical order between the various parts of the institution. To some extent, this conforms to the ideals of the COT where command and instruction is regarded as a tool for achieving efficiency in an organization.

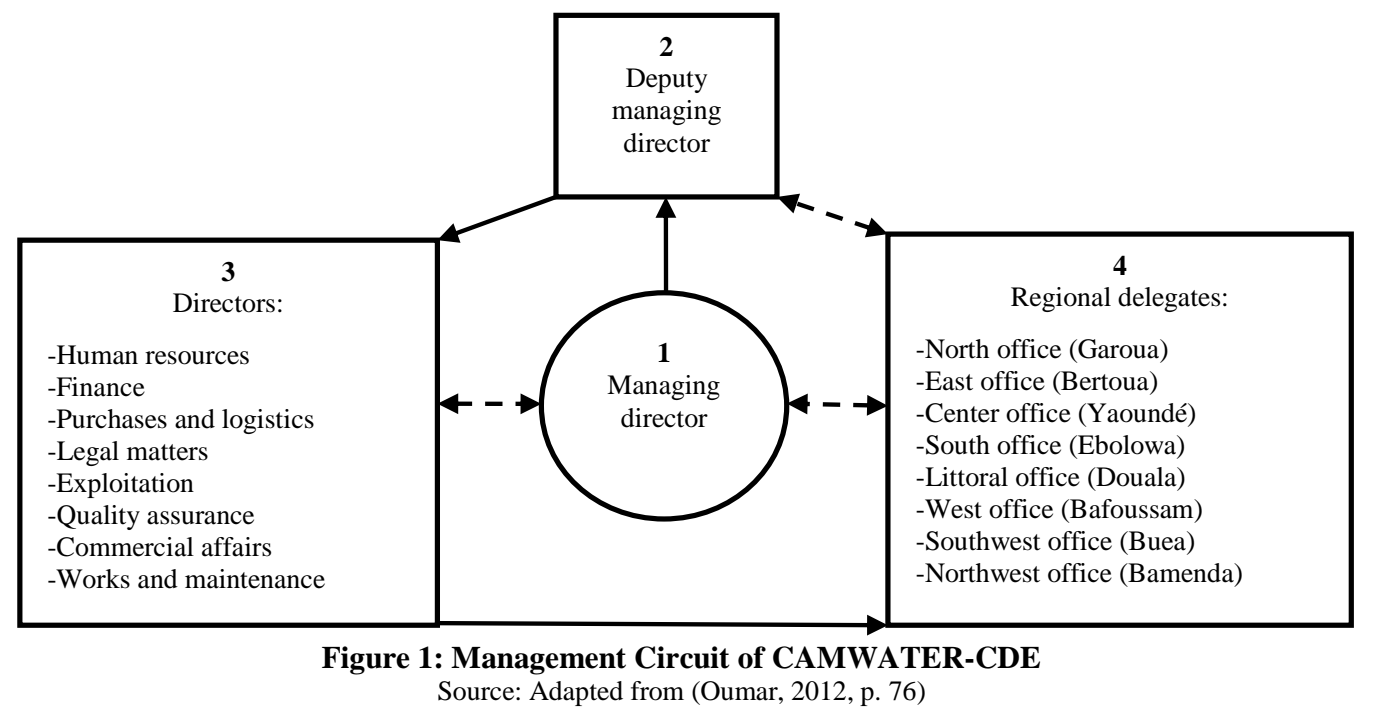

Costs of connection: Water tariffs were revised upward, but the costs of connection were slashed by $50 \%$ on 29 September 2009 to combat poverty and enhance people's access to drinking water and proper sanitation services (RC, 2007a, p. 4). In spite of the reduction in connection fees, customers were still treated unfairly. Table 2 shows the costs of connection to piped water applicable to customers based on criteria defined by the water corporation. At its own discretion, the company provided its workers with a plastic-material connection with a maximum length of five meters $(\mathrm{m})$ and a 15 millimeter $(\mathrm{mm})$ diameter, free of charge, but charged an ordinary customer 39672FCFA [Franc de la Communauté Financière de l'Afrique] (US\$79.344), including all taxes. However, for connections using the same material and extending over the same distance but $20 \mathrm{~mm}$ wide, the corporation collected 17017FCFA (US\$34.034) from its employees and charged 45569FCFA (US\$91.138) to an ordinary customer, all taxes inclusive. Similarly, an employee of the corporation spent 33614FCFA (US\$67.228) as opposed to 66983FCFA (US\$133.966) to get connected over a distance of at most five meters using a plastic material connection with a $40 \mathrm{~mm}$ diameter, taking all taxes into account. For connections of more than five meters in length, the company imposed an additional cost per meter. A staff member was expected to spend 191FCFA (US\$0.382) per meter for a $20 \mathrm{~mm}$ diameter connection, including all taxes, as against 1771FCFA (US\$3.542) for a common customer. For a $40 \mathrm{~mm}$ diameter connection, a company insider was charged 451FCFA (US\$0.902) with all taxes included, and an outsider paid 2722FCFA (US\$5.444). Yet, the rebating of connection costs served the intended purpose only a little, for applicants are often forced to bribe technicians of the CWC before getting the connections done. Else, applicants' files may remain as "keep in view," subjecting consumers to visiting the institution several times for the same matter, or in extreme cases the files may completely disappear from the office, thus requiring the filing of new applications. The transaction costs of this follow-up exercise are very significant to the consumers and may outweigh the costs of connection as approved by the CWC. This is what OET warns about in its reasoning.

Table 2: Connection Costs to Piped Water Network by Status of User in Cameroon as at 1 October 2006

\begin{tabular}{lcccc}
\hline \multicolumn{2}{c}{ Plastic Materials Connection for a Distance of Less or Equal to Five Meters at Varied Diameters } \\
\hline \multicolumn{2}{c}{ Usual Customer User of Water Corporation } & \multicolumn{2}{c}{ Worker of Water Corporation } \\
\hline Diameter (Mm) & Tax Free Costs (FCFA) & Taxed Costs (FCFA) & Tax Free Costs (FCFA) & Taxed Costs (FCFA) \\
\hline 15 & 33268 & 39672 & 0 & 0 \\
20 & 38213 & 45569 & 14270 & 17017 \\
40 & 56170 & 66983 & 28188 & 33614 \\
\hline
\end{tabular}


Table 2 cont.

\begin{tabular}{lcccc}
\hline \multicolumn{4}{l}{ Plastic Materials Connection Additional Costs per Meter Beyond 5 Meters at Varied Diameters } \\
\hline Diameter (Mm) & Tax Free Costs(FCFA) & Taxed Costs (FCFA) & Tax Free Costs (FCFA) & Taxed Costs (FCFA) \\
\hline 15 & 1230 & 1467 & 0 & 0 \\
20 & 1485 & 1771 & 160 & 191 \\
40 & 2283 & 2722 & 378 & 451 \\
\hline
\end{tabular}

Source: (RC, 2007a, p. 13-14)

Water rates: The CWC implemented different water rates for its customers. The water tariffs were revised upward in October 2005 and became effective on 1 October 2006 (RC, 2007a, p. 4). The new rosters of water rates are presented in Table 3. The corporation identified and catalogued six main categories of water consumers in order of the urgency of the need for drinking water. The first category consisting of households, paid 293FCFA (US\$0.586) per cubic meter $\left(\mathrm{m}^{3}\right)$ for water consumption of less or equal to $10 \mathrm{~m}^{3}$, and $364 F C F A$ (US $\left.\$ 0.728\right)$ per $\mathrm{m}^{3}$ for a consumption level above $10 \mathrm{~m}^{3}$. The second group comprising commercial taps, was charged 293FCFA (US\$0.586) per $\mathrm{m}^{3}$ for any level of water consumption. The last category included three groupings comprising administrative buildings (ministries, hospitals), municipal houses (slaughter houses), and municipal taps, and paid 382FCFA (US\$0.764) per $\mathrm{m}^{3}$ irrespective of the volume of water used. The last category included industries, which were placed on different consumption levels with corresponding water tariffs. At consumption level one (CL1), industries paid 382FCFA (US\$0.764) per $\mathrm{m}^{3}$, at level two (CL2) they were charged 366FCFA (US\$0.732) per $\mathrm{m}^{3}$, and at level three (CL3) a rate of 350FCFA (US\$ 0.700) per $\mathrm{m}^{3}$ was applied. Industries placed on level four (CL4) and five (CL5) were required to pay 337FCFA (US\$0.674) per $\mathrm{m}^{3}$ and 322FCFA (US\$0.644) per $\mathrm{m}^{3}$ of water consumed, respectively. Thus, it is evident that households paid the lowest price per $\mathrm{m}^{3}$ of drinking water compared to other customers of the corporation, so long as the level of their consumption did not exceed the limit of $10 \mathrm{~m}^{3}$ for private subscribers. Another striking feature of the system is the introduction of a 71FCFA (US\$0.142) or 24.23\% increase per $\mathrm{m}^{3}$ on the water tariff paid by households in order to discourage them from using more than $10 \mathrm{~m}^{3}$. The scheme is tax-free as drinking water belongs in the class of necessity goods and services of life. Despite this, water from the CWC is not regularly available to users. To minimize disappointment and discomfort, most users compensate by building and maintaining their own wells. This again boils down to consumers incurring additional costs as highlighted by OET.

Table 3: Drinking Water Tariffs by User Type in Cameroon as at 1 October 2006

\begin{tabular}{lccc}
\hline \multicolumn{1}{c}{ User Type } & Consumption Level $\left(\mathbf{m}^{\mathbf{3}}\right)$ & Tariff Codes & Price in FCFA per $\mathbf{~ m}^{\mathbf{3}}$ (Tax Free) \\
\hline Households & Peak of $10 \mathrm{~m}^{3}$ & 500 & 293 \\
Commercial taps & Beyond $10 \mathrm{~m}^{3}$ & 501 & 364 \\
Administrative offices & & $510-511$ & 293 \\
Municipal houses & Any volume & 550 & 382 \\
Municipal taps & & 560 & 382 \\
& CL1 & 600 & 382 \\
& CL2 & 700 & 382 \\
Industries & CL3 & 710 & 366 \\
& CL4 & 720 & 350 \\
& CL5 & 730 & 337 \\
\hline
\end{tabular}

Source: (RC, 2007a, p. 13)

Tax disparities: There is a wide percentage gap in the tax paid by customers of the corporation with regard to the costs of connection to the water supply network. Table 4 shows that a common customer of the corporation paid as much as $100 \%$ more taxes compared to an employee of the company for a connection over a distance of at most 5 meters $(\mathrm{m})$ with a $15 \mathrm{~mm}$ diameter. For a connection of at most $5 \mathrm{~m}$ with a 20 mm diameter, a common customer spent as much as $\mathbf{1 6 7 . 7 8 \%}$ more in taxes than a member of staff of the company. Likewise, a common customer paid as much as $99.28 \%$ more taxes than a member of staff for a connection over a distance of at most $5 \mathrm{~m}$ and $40 \mathrm{~mm}$ diameter. When it came to the costs of connection per additional meter above $5 \mathrm{~m}$, the common customer was once more exploited compared to a staff member. The common customer was charged $100 \%$ more per $\mathrm{m}$ for a $20 \mathrm{~mm}$ diameter connection, $822.58 \%$ more per $\mathrm{m}$ for a $20 \mathrm{~mm}$ diameter connection and $501.36 \%$ more per $\mathrm{mm}$ for a $40 \mathrm{~mm}$ diameter connection, compared to a member of staff of the company. The corporation granted preferential treatment to members of staff to provide incentives to its workers. The policy aimed at instilling in the 
mind of workers a sense of loyalty and dedication to the company. While an attempt towards valuing its workers is intended through the implementation of a tax discrimination policy is in line with HRT arguments, one major weakness of the company remained its inability to effectively and efficiently satisfy the water demand of users. In fact paying more tax to receive satisfactory services is more comforting than disbursing less without acquiring the expected services. So, this policy could have positively impacted the lives of employees if efficient delivery of water services was achieved as suggested by COT. Further, there seems to be a misplacement of priorities vis-à-vis this policy, as the most pressing need for water availability comes next to that of the need for recognition in this specific case, hence a deviation from the teachings of HRT as explained by Maslow's hierarchy of needs theory.

Table 4: Tax Disparities on Connection Costs to Piped Water between Customers as at 1 October 2006

\begin{tabular}{lcccc}
\hline \multicolumn{2}{l}{ Plastic Materials Connection for a Distance of Less or Equal to 5 m at Varied Diameters } \\
\hline \multirow{2}{*}{ Diameter (Mm) } & $\begin{array}{c}\text { Usual Customer of Water } \\
\text { Corporation }\end{array}$ & $\begin{array}{c}\text { Worker of Water } \\
\text { Corporation }\end{array}$ & $\begin{array}{c}\text { Taxed Costs Difference } \\
\text { between Customers }\end{array}$ \\
\cline { 2 - 5 } & Taxed Costs (FCFA) & Taxed Costs (FCFA) & Absolute & Percentage (\%) \\
\hline 15 & 39672 & 0 & 39672 & +100 \\
20 & 45569 & 17017 & 28552 & +167.78 \\
40 & 66983 & 33614 & 33369 & +99.28 \\
\hline Plastic Material Connection Additional Cost per Meter Beyond 5m at Varied Diameters & Percentage (\%) \\
\hline Diameter (Mm) & Taxed Costs (FCFA) & Taxed Costs (FCFA) & Absolute & +100 \\
\hline 15 & 1467 & 0 & 1467 & +822.58 \\
20 & 1771 & 191 & 1580 & +501.36 \\
40 & 2722 & 451 & 2271 & \\
\hline
\end{tabular}

Source: (RC, 2007a, pp. 13-14)

\subsection{Achievements}

The successes of the corporation are examined with regard to the grid subscription, area coverage, and water production and distribution of the corporation.

Grid subscription: Table 5 displays the statistics for network subscriptions to the CWC for 2000-2007. It shows that the number of subscriptions to the water supply network of 170,264 subscribers in 2000 grew by $5.86 \%$ in 2001, 7.85\% in 2002, and a substantial 15.54\% in 2003. It continued to grow in 2004 and 2005 but at less than $9 \%$. Yet, in 2006 , it fell by $4.84 \%$, before regaining growth at the rate of $8.56 \%$ in 2007 . The increases achieved in the subscription to the water network before 2006 are associated with people's rush to subscribe ahead of anticipated cost increases after the take-over of the company by the private sector. Once more, this substantiates the arguments on transactional costs advanced by OET.

Table 5: Grid Subscription to the Cameroon Water Corporation, 2000-2007

\begin{tabular}{lcccccccc}
\hline \multirow{2}{*}{ Variable } & \multicolumn{9}{c}{ Year } \\
\cline { 2 - 9 } & $\mathbf{2 0 0 0}$ & $\mathbf{2 0 0 1}$ & $\mathbf{2 0 0 2}$ & $\mathbf{2 0 0 3}$ & $\mathbf{2 0 0 4}$ & $\mathbf{2 0 0 5}$ & $\mathbf{2 0 0 6}$ & $\mathbf{2 0 0 7}$ \\
\hline Subscriptions & 170264 & 180245 & 194405 & 224630 & 233100 & 251666 & $239486(\mathbf{e})$ & $260000(\mathbf{e})$ \\
Percentage $(\%) *$ & - & +5.86 & +7.85 & +15.54 & +3.77 & +7.96 & -4.84 & +8.56 \\
\hline
\end{tabular}

Sources: (National Institute of Statistics [NIS], 2006, p. 278); (e) (RC, 2007b, Annexe 3, p. 4). * Authors: The calculation is based on simple operations of cross multiplication and division.

Area coverage: Table 6 presents the area coverage of the CWC for 2000-2007. It indicates that the expansion of the water supply network across the country moved from a coverage of 4200 kilometers $(\mathrm{Km})$ in 2000 to $4474 \mathrm{Km}$ in 2005 , representing an absolute increment of $274 \mathrm{Km}$ or a relative increase of $6.52 \%$ under SNEC. With the advent of the Cameroon Water Utilities Corporation, Camerounaise des Eaux (CAMWATER-CDE), in 2006 , the water supply network shrank by $15 \mathrm{Km}$ or $0.33 \%$ before increasing by $541 \mathrm{Km}$ or $12.13 \%$ in 2007 . In other words, between 2000 and 2007, the water supply network expanded by $800 \mathrm{Km}$ (that is, the difference between the coverage for 2007 and the coverage for 2000 , being $5000-4200=800$ ) or $19.04 \%$ across the country. Further, the rate of efficiency (effective proportion of users served among subscribers) of $92 \%$ of the water distribution network in 2000 increased by one percentage point every year through 2003 and two percentage points in 2004, but drastic falls of 14 percentage units and 6.51 percentage units followed in 2005 and 2006, respectively. Although the supply network witnessed growth with a reasonable rate of people's access to drinking water, this occurred only before the 
takeover of the CWC by the corporate sector in 2006. The period after the change of ownership of the company experienced poor performance owing to the upward revision of water tariff in the face of intermittent water delivery, which ended up depressing and discouraging users from patronizing the company. The claims of OET explain to some extent the retraction of users in the present situation.

Table 6: Area Coverage of the Cameroon Water Corporation, 2000-2007

\begin{tabular}{|c|c|c|c|c|c|c|c|c|}
\hline \multirow{2}{*}{ Variable } & \multicolumn{8}{|c|}{ Year } \\
\hline & 2000 & 2001 & 2002 & 2003 & 2004 & 2005 & 2006 & 2007 \\
\hline Coverage $(\mathrm{Km})$ & $4,200^{*}$ & 4,188 & 4,212 & $4,285^{*}$ & $4,443 *$ & $4,474 *$ & $4,459 *$ & $5,000(\mathbf{d})$ \\
\hline Variation * & - & -12 & +24 & +73 & +158 & +31 & -15 & +541 \\
\hline Grid efficiency (\%) & 92.00 & 93.00 & 94.00 & 95.00 & 97.00 & 83.00 & $76.49(\mathbf{e})$ & $77.00(\mathbf{e})$ \\
\hline Percentage variation $(\%)^{*}$ & - & +1 & +1 & +1 & +2 & -14 & -6.51 & +0.51 \\
\hline
\end{tabular}

Sources: (NIS, 2006, p. 278), (d) (Pibasso, 2008, p. 1), (e) (RC, 2007b, Annexe 3, p. 4). * Authors: Calculated on simple addition and subtraction operations basis.

Water production and delivery: In spite of the troubles that surrounded the CWC, little successes in providing drinking water and sanitation services were registered. The former Société National des Eaux du Cameroun (SNEC) - Cameroon National Water Corporation - became defunct in 2005 and was split in 2006 into the Cameroon Water Utilities Corporation (CAMWATER) and Camerounaise des Eaux (CDE). The period from the date of the creation of SNEC in 1967 to 2005 technically corresponded to the period of state ownership of the company. The total assets of SNEC in 1994 were valued at 203.8 billion FCFA (US $\$ 407.6$ million) with a turnover of 13 billion FCFA (US\$26 million) and 2176 employees (NIS, 2006, p. 278). A brief account of the successes credited to the company over the period 2000 to 2005 is presented in Table 7. Thus, between 2000 and 2005, SNEC produced varied amounts of drinking water for distribution to users across the country. From a total production of $92486467 \mathrm{~m}^{3}$ of water in 2000 , the quantity produced dropped by $1.25 \%$ in 2001 after which it started to grow every year. The year 2002 registered a $6 \%$ increase over the volume produced in 2001, while the year 2003 recorded a $2 \%$ increase over the quantity provided in 2002. Similarly, the year 2004 achieved a 1.37\% improvement, whilst in 2005 an increase of $20 \%$ in the amount of water realized in 2004 was obtained. Although the annual demand for drinking water in the country increased, the quantities produced were adequate enough to support the requests of users. Users consumed $51710872 \mathrm{~m}^{3}$ of drinking water in 2000, after which increases were recorded every year. In 2001 there was an increase of $6.16 \%$; in 2002 the increase was $4 \%$; and in the following three years, that is, 2003, 2004, and 2005 , the observed increases stood at $7.49 \%, 7.20 \%$, and $3.44 \%$, respectively.

A careful observation of the production and consumption pattern of drinking water for 2000-2005 reveals that while more water was produced, less was consumed owing to the high rate of leakage from the water pipes. The rate of leakage varied from one year to the other. It was $44.08 \%$ in 2000 and $39.88 \%$ in 2001. For the year 2002, the rate of leakage was $41.10 \%$ and in 2003 it was $37.89 \%$. However, in 2004 and 2005 the rates of leakage were $34.28 \%$ and $43.35 \%$, respectively. From 2000 to 2005, the rate of leakage as a proportion of total production averaged $40.08 \%$ (that is, a horizontal summation of gaps as a percentage of production for the years spanning 2000 to 2005 divided by the number of observations, being $240.53 \div 6=40.08$ ). The high rate of leakage is in line with people's perception of negligence towards public goods, generally regarded in the country as belonging to nobody to the extent that, if they are not misappropriated for personal interest, then they are recklessly handled. This is undesirable behavior for organizational success, hence the need for in-depth organizational change that inculcates behavior that is mindful of collective property as supported by CCOT.

Table 7: Successes of SNEC in Drinking Water Distribution, 2000-2005

\begin{tabular}{|c|c|c|c|c|c|c|}
\hline \multirow{2}{*}{ Variable } & \multicolumn{6}{|c|}{ Year } \\
\hline & 2000 & 2001 & 2002 & 2003 & 2004 & 2005 \\
\hline Production $\left(\mathrm{m}^{3}\right)$ & 92486467 & 91322628 & 96844738 & 98640501 & 100000000 & 120000000 \\
\hline Percentage $(\%)^{*}$ & - & -1.25 & +5.70 & +1.88 & +1.37 & +20 \\
\hline Consumption $\left(\mathrm{m}^{3}\right)$ & 51710872 & 54900274 & 57040562 & 61314160 & 65715000 & 67980000 \\
\hline Percentage $(\%)^{*}$ & - & +6.16 & +3.89 & +7.49 & +7.20 & +3.44 \\
\hline $\begin{array}{l}\text { Gap (Production - Consumption in } \\
\left.\mathrm{m}^{3}\right)^{*}\end{array}$ & 40775595 & 36422354 & 39804176 & 37326341 & 34285000 & 52020000 \\
\hline Gap as Percentage of Production* & 44.08 & 39.88 & 41.10 & 37.84 & 34.28 & 43.35 \\
\hline
\end{tabular}


With the split of the SNEC, the period after 2005 propels the CWC into the era of the CMAWATER-CDE involvement in the provision of drinking water and sanitation services in Cameroon. The accomplishments of the CWC beyond 2005 are displayed in Table 8 . The table shows that the volume of water produced in 2010 increased by $1.44 \%\left(140\right.$ million $\left.\mathrm{m}^{3}\right)$ from the previous year's volume $\left(138\right.$ million $\left.\mathrm{m}^{3}\right)$ and rose by $2.98 \%$ in 2009 from the estimate for the year 2008 (134 million $\left.\mathrm{m}^{3}\right)$ as a result of the company's efforts to accommodate the increasing water needs of people in the country. The volume of water sold to consumers between 2008 and 2010 followed a similar pattern, with a $2.53 \%$ increase in $2010\left(105\right.$ million $\left.\mathrm{m}^{3}\right)$ from the 2009 estimate, and a $1.23 \%$ increase in 2009 $\left(103.7\right.$ million $\left.\mathrm{m}^{3}\right)$ from the 2008 estimate $\left(101.16\right.$ million $\left.\mathrm{m}^{3}\right)$. However, the networking coverage remained relatively similar at a $1.5 \%$ increase on average between 2008 and 2010, due to the long waiting time of subscribers before connections are done, coupled with the acute shortage of technical personnel who attend to or delay attending to applications on the basis of personal interest and affinities. Finally, it is observed that subscription rates have substantially increased by $9.37 \%$ (35 thousand subscribers) in 2010 from the 2009 estimate (32 thousand subscribers) and by $45.45 \%$ in 2009 from the 2008 estimate (22 thousand subscribers) owing to the rising demand for drinking water and sanitation services by people in the country.

Table 8: Successes of CAMWATER-CDE in Drinking Water Delivery, 2008-2010

\begin{tabular}{|c|c|c|c|}
\hline \multirow{2}{*}{ Variable } & \multicolumn{3}{|c|}{ Year } \\
\hline & 2008 & 2009 & 2010 \\
\hline Investment & $\begin{array}{l}\text { 21950000000FCFA } \\
\text { (US\$43.900000) }\end{array}$ & $\begin{array}{l}29.504000000 \mathrm{FCFA} \\
\text { (US\$59008000) }\end{array}$ & $\begin{array}{l}\text { 44131000000FCFA (US\$88262000) for water } \\
\text { delivery, 3360000000FCFA (US } \$ 6720000 \text { ) for } \\
\text { new water production centers }\end{array}$ \\
\hline Subscriptions & 280000 & 320000 & 350000 \\
\hline Networking & $79 \%$ & $81 \%$ & $82 \%$ \\
\hline Production & $\begin{array}{l}134000000 \mathrm{~m}^{3} \text { but } \\
101158536 \mathrm{~m}^{3} \text { sold } *\end{array}$ & $\begin{array}{c}138000000 \mathrm{~m}^{3} \text { but } \\
103719512 \mathrm{~m}^{3} \text { sold } *\end{array}$ & $\begin{array}{l}140000000 \mathrm{~m}^{3} \text { but } \\
105000000 \mathrm{~m}^{3} \text { sold }\end{array}$ \\
\hline $\begin{array}{l}\text { Consumer } \\
\text { welfare }\end{array}$ & \multicolumn{3}{|c|}{$\begin{array}{l}\text { Exemption of households from water consumption value added tax, attainment of status of strategic } \\
\text { enterprises protected from payment of registration fees granting } 50 \% \text { tax rebate }\end{array}$} \\
\hline Maintenance & \multicolumn{3}{|c|}{ Connection census in public services, water conservation methods campaign and leakages repairs } \\
\hline
\end{tabular}

Although the area covered by the company expanded by $800 \mathrm{Km}$ or $19.04 \%$ between 2000 and 2007 , the rate of water leakage within the period was on average as high as $40.08 \%$. The network efficiency of the corporation declined by 15 percentage points, while water tariffs for domestic consumption increased by $8.11 \%$, but worked out at an average of $24.35 \%$ across all categories of users during the same period. Ordinary customers paid on average $122.35 \%$ more taxes to acquire a network connection, compared to employees of the company under normal circumstances, and in the case of extra connection measurement requirements; ordinary customers paid $474.64 \%$ more taxes than employees. Overall, this leads to the conclusion that a lot needs to be done to bring drinking water to users in order to uplift their living standard.

\subsection{Constraints}

From inception in 1967 to 2013, the CWC faced different socio-politico-economic situations that impacted on its performance over the years. The company passed through periods of affluence and turmoil. Consequently, the corporation endured technical, political, managerial and financial deficits.

Technical constraints: The technical difficulties of the corporation, as summarized in Table 9, included the limited access of the population to drinking water and sanitation services and incomplete connections inherited from SNEC (CDE Pamphlet, Greenwhich Edition, n.d.). The incomplete expansion of water production facilities inherited from SNEC, the lack of spare parts for replacement of obsolete devices in urgent cases, and the lack of a skilled neighborhood service to attend to repairs and technical complaints at most water production plants were other technical limitations for the corporation. The absence of qualified staff in water production centers placed strain on technicians from Douala or Yaoundé who had to travel long distances to peripheral centers to do repairs (Ngnikam, 2007, p. 19). Such shortcomings stem from the failure of the CWC to initiate a contextual change in its activities so as to adapt and update itself to environmental necessities by securing high performance devices and skilled 
personnel, rather than pretending and tolerating mediocrity at low short-run costs but with significant consequences in the long run. Thus, one observes a deviance of the CWC from the values of CCOT by its reticence to embrace technological progress.

Table 9: Technical Constraints of the CWC

\begin{tabular}{|c|c|}
\hline Constraint Type & Effect \\
\hline $\begin{array}{l}\text {-Incomplete connections inherited from SNEC } \\
\text {-Lack of spare parts for replacement of obsolete devices } \\
\text {-Lack of skilled district service at most water production plants } \\
\text {-Absence of qualified manpower in water production centers }\end{array}$ & $\begin{array}{l}\text {-Limited access of people to drinking water } \\
\text {-Regular interruptions of supply of drinking water } \\
\text {-Limited operational water production plants } \\
\text {-High mobility of technicians from Douala or Yaoundé to } \\
\text { peripheral centers }\end{array}$ \\
\hline
\end{tabular}

Source: (Ngnikam, 2007, p. 19)

Political constraints: Despite the return of Cameroon to democracy in 1990, the style of governance in the country remained inflexible and highly focused on the executive power. Subjective appointments to politically sensitive posts continued and the release of financial information of establishments partially or fully run by the government remained out of bounds. As a result, the CWC could not publicize any potentially controversial information without the prior authorization of the Ministry of Energy and Water Resources (MEWR) on behalf of the central government. In the past, top officials have been sacked for leaking politically sensitive information about the company to the public without approval from the hierarchy. Table 10 recapitulates the discussion. The fact that appointments and the release of financial information about the CWC are closely monitored by the central government reflects that officials are not responsive to the needs of the electorate, but are only concerned with participating in political games to perpetuate their power or control over resources, through nepotism, sycophancy, and lack of transparency, at the expense of the governed. This describes an unequivocal departure from good governance practice as articulated in PPOT.

Table 10: Political Constraints of the CWC

\begin{tabular}{ll}
\hline \multicolumn{1}{c}{ Constraint Type } & \multicolumn{1}{c}{ Effect } \\
\hline -Rigid style of governance in the country & -Centralization of power on the executive arm of government \\
-Subjective appointments to crown delicate posts & -Prohibited release of financial position of public institutions \\
\hline Sources: Authors' observation &
\end{tabular}

Managerial constraints: Customers of the CWC faced cumbersome procedures before obtaining connections to the water supply grid and unsatisfactory conditions for the payment of bills (CDE Pamphlet, Greenwhich Edition, n.d.). Workers embarked on industrial action demanding improved welfare and social benefits and claiming unpaid salaries and better working conditions (Mbunwe \& Pefok, 2009, pp. 1-2). In some water production centers, the cost of exploitation was high owing to an overestimation of the installed production capacity, there was a drinking water shortage, and supply interruptions were frequent due to irregular payment of water bills by those using commercial water taps (Ngnikam, 2007, p. 19). A recap of the discussion is given in Table 11. Judging from the way customers and workers are treated, and water production centers are managed, it is evident that the teachings of OET and NCOT are less integrated in the CWC. This is so because customers pay for extra costs and employees are not valued.

Table 11: Managerial Constraints of the CWC

\begin{tabular}{ll}
\hline \multicolumn{2}{c}{ Constraint Type } \\
\hline -Cumbersome procedures of water connections and & -Long waiting time to get water connection and pay bills \\
unsatisfactory conditions for payment of bills & -Irregular payment of water bills by users \\
-High exploitation cost in some water production centers & -Frequent drinking water shortage and supply interruptions \\
\hline Sources: (CDE Pamphlet, Greenwhich Edition, n.d.); (Mbunwe and Pefok, 2009, pp. 1-2); (Ngnikam, 2007)
\end{tabular}

Financial constraints: The cost of connection of 150 thousand FCFA (US\$300) is extremely high for the majority of households whose income averages 45 thousand FCFA (US\$90) per month. Furthermore, the corporation has over time accumulated unpaid water bills from the state and public services, such as slaughterhouses and hospitals (Ngnikam, 2007, p. 17). The financial debt from these institutions was valued at 16 billion FCFA (US\$32 million) between 2008 and 2009. The company's bad debts stood at 30.997 billion FCFA (US\$61.994 
million) in 2010 (RC, 2007b, Annexe 3, p. 15). A specimen of the Corporation's unsettled water bills from large consumers in 1993 and 1999 is presented in Table 12. It shows that as of 30 June 1993, the state and councils all over the country owed about 30 billion FCFA (US\$60 million) to SNEC, of which municipalities accounted for 19\% and the share of the state represented $81 \%$ of the total (NABC File Rd [1991]1, pp. 98-101). This trend plunged the SNEC into financial disarray that culminated in a gross loss of about 5 billion FCFA (US\$10 million) in 1994 (World Bank, 2010, p. 4). Furthermore, the bad debts scenario from big consumers continued to threaten the financial position of the SNEC in subsequent years, leading to significant decreases in its revenue collection. A sample of outstanding bills of the corporation from only two municipalities - the Limbe Urban Council (LUC) and Buea Rural Council (BRC) - shows that the two councils were indebted to the tune of 1.009 billion FCFA (US\$2.019 million) to the SNEC in 1999. Of the total amount, the LUC was responsible for $39 \%$ against $61 \%$ for the BRC (NABC File Rd [1991]1, pp. 466-467, 473). The financial troubles that occasioned the poor performance and precipitated the fall of the CWC are associated with the inability of the company to enforce the collection of bills from and interrupt supplies to municipalities due to recurrent government interference aimed at mitigating the anger of the masses who received drinking water free of charge from the councils. This describes a strategy designed by political players to maintain power and continue controlling the resources as explained by PPOT.

Table 12: Arrears Owed to SNEC by Municipalities and the State in 1993 and 1999

\begin{tabular}{lccc}
\hline \multicolumn{2}{c}{ Country (1993) } & \multicolumn{2}{c}{ Some Councils (1999) } \\
\hline \multicolumn{1}{c}{ Debtor } & Amount (FCFA) & Debtor & Amount (FCFA) \\
\hline All municipalities & $5586349884(19)$ & Limbe Urban Council & $395000000(39)$ \\
State & $24241186225(81)$ & Buea Rural Council & $614658952(61)$ \\
Total & $29827536109(100)$ & Total & $1009658952(100)$ \\
\hline Source: (NABC, File Rd [1991]1.Water supplies-SNEC 1991, pp. 98-101, 466-467, 473). NB: Values in brackets represent percentages of total.
\end{tabular}

\subsection{Prospects}

The few successes achieved by the CWC against all odds, generate hope for better access for households to drinking water in the future. At both the domestic and global levels, the country received support from development partners for the implementation of more water investment projects.

Domestic level: CAMWATER, the representative of the state in collaboration with its private partner CDE, in the business of providing drinking water and sanitation services, has undertaken to double efforts towards investment in the water sector in the years to come (CAMWATER, 2007, p. 4). The GC has committed itself to facilitate the installation of a manual borehole or well for drinking water supply to every community of 300 to 500 people, so as to achieve $47 \%$ access to drinking water in rural areas and more than $50 \%$ in urban centers of the country by 2016 (CAMWATER, 2007, p. 4). For the two megacities of Douala and Yaoundé, the target for access to drinking water by 2016 is set at 53\%. To achieve this goal, the water corporation is expected to sell 145 million $\mathrm{m}^{3}$ of drinking water to 555 thousand subscribers across the country by 2016 (CAMWATER, 2007, p. 4), compared to 67.98 million $\mathrm{m}^{3}$ of drinking water sold to 251,666 subscribers in 2005 (NIS, 2006, p. 278). Based on these statistics, the water corporation needs to increase the volume of water sold by $113.29 \%$, and the size of the population served with drinking water by $120.53 \%$. Applying the current water tariff of 293FCFA (US\$0.586) per $\mathrm{m}^{3}$ (CDE, 2008) as a flat rate on the volume sold to subscribers, the returns to the water corporation by 2016, are anticipated to rise by 22.566 billion FCFA (US\$45.133million) more than the total sales of 1.99 billion FCFA (US\$39.83 million) in the year 2005. A report from the state indicates that the GC has planned to create more connections with a view to reaching a peak of 350 thousand connections by 2015 (RC, 2007a, p. 4). A summary of the discussion is presented in Table 13. Yet, these ambitions require sincere commitment and will from political leaders to enforce good governance in accordance with the demands of PPOT in order to attain efficiency. 
Table 13: Promises of CAMWATER-CDE for Better Drinking Water and Sanitation Services

\begin{tabular}{ll}
\hline \multicolumn{1}{c}{ Structure } & \multicolumn{1}{c}{ Pledge } \\
\hline & -Provision, development, renovation, extension, funding of water physical structures, and monitoring \\
& activities of water sector by CAMWATER \\
& -Exploitation, distribution, commercialization, maintenance of structures, constant improvement of \\
& drinking water access rate, improvement of quality of water, and sanitation services by CDE \\
& -Creation of 350,000 connections by 2015, promotion of development of small business water operators, \\
& restoration of available public sanitation amenities, and promotion of cheap community based sanitation \\
CAMWATER- & practices in the country \\
CDE & -Replenishment of $20 \mathrm{~km}$ of $100 \mathrm{~mm}$ breadth pipes and 5,000 off meter subscribed connections yearly \\
& based on provisions of article 29 of concession contract and article 21 of performance contract, yearly \\
& public awareness on water management issues and the need for real price of water \\
& -Drinking water access targeted at 53\% for Douala and Yaoundé by 2016 \\
& -Drafting of annual report by end of March of every year on the performance of CDE \\
& -Yearly provision of performance indicators on water supply by CDE to CAMWATER for evaluation and \\
& confrontation with requirements of the performance contract \\
\hline Sources: (RC, 2007a, pp. 4-5); (RC, 2007b, Annexe 3, pp. 4, 9-11, 15); (CAMWATER, 2007, p. 4); (CDE Pamphlet, Greenwhich Edition, n.d.)
\end{tabular}

In the area of capital water projects, CAMWATER has initiated various water development projects for which assistance or partnership is needed from local stakeholders. Table 14 displays a list of proposals to be executed across the country and some localities identified by CAMWATER as being in dire need of additional water provisioning. If these projects receive the required support, CAMWATER anticipates enhancing the access of households to drinking water and sanitation services in these localities by 2020. The total cost of the proposed projects stands at 22.934 billion FCFA (US\$45.869 million) or 6.97\% of the total investment envelope of 328.8965 billion FCFA (US\$657.793 million). The water development proposals have some common features. They revolve around the rehabilitation of the water network system and equipment, capacity building, disinfection of the water network, demarcation of water catchment areas, construction of water treatment and distribution centers, erection of water distribution channels, and the creation of water storage facilities. Country proposals were to be fully sponsored, whereas each project in a given locality was partly funded by CAMWATER at 25\% of its estimated cost, except for that of Limbe for which CAMWATER did not provide estimates. To concretize the 2020 objective, the CWC needs to implement good governance rules as underlined by PPOT and adjust its practices in line with the requirements of the MST.

Table 14: Water Development Plans of CAMWATER for the Country and Selected Localities

\begin{tabular}{|c|c|c|c|c|}
\hline Parameter & Project Proposal & Target & Costs (FCFA) & $\begin{array}{c}\begin{array}{c}\text { Percentage Contribution } \\
\text { of CAMWATER }\end{array} \\
\end{array}$ \\
\hline Country (f) & $\begin{array}{l}\text {-Rehabilitation, } \\
\text { expansion of water } \\
\text { supply network } \\
\text { and capacity } \\
\text { building }\end{array}$ & $\begin{array}{l}\text {-Refurbishment of all water } \\
\text { production centers by } 2015 \\
\text {-Creation of more connections by } \\
2015 \\
\text {-Reinforcement of expertise on water } \\
\text { management issues by } 2015\end{array}$ & $\begin{array}{l}30000000000 \\
185000000000 \\
5000000000\end{array}$ & 100 \\
\hline Bangangte & $\begin{array}{l}\text {-Rehabilitation of } \\
\text { water network } \\
\text { system }\end{array}$ & $\begin{array}{l}\text {-Increase current daily volume of } \\
\text { water production of } 1000 \text { cubic } \\
\text { meters }\left(\mathrm{m}^{3}\right) \text { to } 3265 \mathrm{~m}^{3} \text { per day to } \\
\text { meet water demand for estimated } \\
100 \% \text { increase in current population } \\
\text { of } 50000 \text { people by } 2020\end{array}$ & 5085000000 & 25 \\
\hline Buea & $\begin{array}{l}\text {-Rehabilitation of } \\
\text { civil engineering } \\
\text { projects and } \\
\text { equipments }\end{array}$ & $\begin{array}{l}\text {-Augment present daily volume of } \\
\text { water production of } 6500 \mathrm{~m}^{3} \text { to } 9,030 \\
\mathrm{~m}^{3} \text { per day to satisfy water demand } \\
\text { for estimated double of current } \\
\text { population of } 100,000 \text { people by } 2020\end{array}$ & 600000000 & 25 \\
\hline
\end{tabular}


Table 14 cont.

\begin{tabular}{|c|c|c|c|c|}
\hline Ebolowa & $\begin{array}{l}\text {-Disinfection of } \\
\text { water network } \\
\text {-Curving of water } \\
\text { catchment areas } \\
\text {-Construction of } \\
\text { water treatment } \\
\text { centers }\end{array}$ & $\begin{array}{l}\text {-Boost existing daily volume of water } \\
\text { production of } 2560 \mathrm{~m}^{3} \text { to } 5870 \mathrm{~m}^{3} \text { per } \\
\text { day by } 2020 \text { to account for water } \\
\text { needs of population growing at } \\
\text { estimated rate of } 3 \% \text { per annum }\end{array}$ & 3479000000 & 25 \\
\hline Kribi & $\begin{array}{l}\text {-Construction of } \\
\text { treated water } \\
\text { distribution centers }\end{array}$ & $\begin{array}{l}\text {-Enhance current daily volume of } \\
\text { water production of } 1,300 \mathrm{~m}^{3} \text { to } 4335 \\
\mathrm{~m}^{3} \text { per day to cover water demand for } \\
\text { estimated } 81 \% \text { increase in current } \\
\text { population of } 48,000 \text { people by } 2020\end{array}$ & 4979000000 & 25 \\
\hline Sangmelima & $\begin{array}{l}\text {-Erection of water } \\
\text { distribution } \\
\text { channels }\end{array}$ & $\begin{array}{l}\text {-Amplify present daily volume of } \\
\text { water production of } 1,000 \mathrm{~m}^{3} \text { to } 4525 \\
\mathrm{~m}^{3} \text { per day by } 2020 \text { to cover water } \\
\text { demand shortfall of a fast growing } \\
\text { population }\end{array}$ & 4721500000 & 25 \\
\hline Limbe & $\begin{array}{l}\text {-Creation of water } \\
\text { storage facilities }\end{array}$ & $\begin{array}{l}\text {-Raise volume of water availability to } \\
\text { adequately match water needs of } \\
\text { population of the city by } 2020\end{array}$ & 1370000000 & - \\
\hline \multicolumn{3}{|l|}{ Total } & 328896500000 & - \\
\hline
\end{tabular}

Sources: (f) (RC, 2007a, p. 6); (RC, 2007b, Annexe 3, p. 15); (CAMWATER, 2007, pp. 6-7)

Worldwide level: At the level of international co-operation, development partners have put various types of funding packages at the disposal of CAMWATER for the development of water supply infrastructures to improve the availability of drinking water in Cameroon. The funding, which was estimated at 113 billion FCFA (US\$226 million) includes assistance, donations, and loans. Table 15 presents an inventory of international offers made to CAMWATER along with their aims. Here too, the requisite for good governance in line with the claims of PPOT is imperative for enhancement of drinking water availability.

Table 15: International Investment Bids Granted to CAMWATER by Development Partners

\begin{tabular}{|c|c|c|c|}
\hline Institution & Type of Offer & Value of Offer (FCFA) & Aims of Offer \\
\hline $\begin{array}{l}\text { European Investment } \\
\text { Bank }\end{array}$ & Assistance & 26000000000 & $\begin{array}{l}\text {-Provision of water in } 32 \text { localities of more than } \\
50,000 \text { people across the country } \\
\text {-Rehabilitation, extension, and reinforcement of } \\
\text { water network systems of Douala and Yaoundé }\end{array}$ \\
\hline Eximbank of China & Loan & 11000000000 & $\begin{array}{l}\text {-Reinforcement of water production in Douala } \\
\text { using Mungo River resources }\end{array}$ \\
\hline $\begin{array}{l}\text { French Development } \\
\text { Agency }\end{array}$ & Assistance & 26000000000 & $\begin{array}{l}\text {-Stabilization of water networking system and } \\
\text { rehabilitation of water production centers of } \\
\text { Bertoua, Douala, and Edea } \\
\text {-Strengthening of drinking water production in the } \\
\text { Mefou-Messa Complex in Yaoundé }\end{array}$ \\
\hline Government of Japan & Donation & 10000000000 & $\begin{array}{l}\text {-Promotion of activities of water sector where } \\
\text { necessary in the country }\end{array}$ \\
\hline World Bank & Loan & 40000000000 & $\begin{array}{l}\text {-Institutional capacity building in water } \\
\text { management } \\
\text {-Networking and rehabilitation of urgent water } \\
\text { works } \\
\text {-Renewal and rehabilitation of water physical } \\
\text { infrastructures }\end{array}$ \\
\hline $\begin{array}{l}\text { United States Trade and } \\
\text { Development Agency }\end{array}$ & Assistance & Pending & $\begin{array}{l}\text {-Technical support in feasibility studies and } \\
\text { planning of water projects }\end{array}$ \\
\hline Total & & 113000000000 & - \\
\hline
\end{tabular}

Source: (CAMWATER, 2007, pp. 4-6) 


\subsection{Reliability and Future Performance of the Corporation}

Before running the Chi-square analysis on people's judgment of the reliability and future performance of the CWC, it is important to examine the demographic characteristics of the respondents in the study area to understand the driving forces behind their points of view. These characteristics are presented in Table 16 and discussed accordingly in subsequent lines. A scrutiny of the Table 16 reveals that out of the 110 respondents, men constitute the majority of the study population at $58.18 \%$ (64 respondents) with $41.81 \%$ (46 respondents) being women, which coincides with the population profile of the country. Further, it indicates that unmarried people make up $48.18 \%$ (53 respondents) as opposed to $51.81 \%$ for married people in the study area. The relatively high rate of married people in the study area reflects the respect that African social values confer on married people. Furthermore, it shows that $88.17 \%$ (97 respondents) of the study's population group is dominated by people of less than 50 years old, compared to only $11.71 \%$ ( 13 respondents) for people aged between 50 and 59 years old, given that the country has a broad base pyramid of ages, implying that it has a relatively young population. Besides, it displays that $54.53 \%$ (60 respondents) of the population in the study area has attained secondary-level education and $45.45 \%$ (50 respondents) has reached tertiary-level education owing to limited financial family support and poverty that hold people back from pursuing higher levels of education in the country. It also presents employment statistics of the study area, with $30.90 \%$ (34 respondents) being unemployed people, consisting mainly of students, and $78.18 \%$ ( 86 respondents) being employed people in the following sectors: farming with $18.18 \%$ ( 20 respondents), business with $20.90 \%$ (23 respondents), and government service with $30 \%$ (33 respondents). The high rate of unemployment in the study area is associated with the limited jobs opportunities for youths and the habit of obstinately recycling into offices government workers who are due for retirement in the country. Finally, it explains that $47.27 \%$ (52 respondents) of the study population lives in the rural area in contrast to $52.72 \%$ (58 respondents) that resides in the urban area where living condition is cheaper compared to that obtained in cities.

Table 16: Demographic Characteristics of Respondents

\begin{tabular}{|c|c|c|}
\hline Parameter & Frequency & Percentage $(\%)$ \\
\hline Gender & - & - \\
\hline Male & 64 & 58.18 \\
\hline Female & 46 & 41.81 \\
\hline Total & 110 & 100 \\
\hline Marital Status & - & - \\
\hline Single & 53 & 48.18 \\
\hline Married & 57 & 51.81 \\
\hline Total & 110 & 100 \\
\hline Age Group & - & - \\
\hline $20-29$ & 43 & 39.09 \\
\hline $30-39$ & 38 & 34.54 \\
\hline $40-49$ & 16 & 14.54 \\
\hline $50-59$ & 8 & 7.27 \\
\hline $60-69$ & 5 & 4.54 \\
\hline Total & 110 & 100 \\
\hline Level of Education & - & - \\
\hline Primary & 25 & 22.72 \\
\hline Secondary & 35 & 31.81 \\
\hline Tertiary & 50 & 45.45 \\
\hline Total & 110 & 100 \\
\hline Profession & - & - \\
\hline Student & 34 & 30.90 \\
\hline Farmer & 20 & 18.18 \\
\hline Business operator & 23 & 20.90 \\
\hline Civil servant & 33 & 30.00 \\
\hline Total & 110 & 100 \\
\hline Residential Area & - & - \\
\hline Rural & 52 & 47.27 \\
\hline Urban & 58 & 52.72 \\
\hline Total & 110 & 100 \\
\hline
\end{tabular}

Source: Authors 
Table 17 reflects the points of view of respondents on the ability of the CWC to effectively deliver drinking water and sanitation services to people in the country. It shows that $21.81 \%$ ( 24 respondents) of the population believes in the capability of the CWC to provide the intended services, $26.36 \%$ (29 respondents) of it is reserved on the matter, while $51.81 \%$ (57 respondents) doubts the ability of the CWC to properly offer the anticipated services in the country. A careful reading of Table 17 reveals that more than half of the population is pessimistic about good performance of the CWC in future, owing to past bitter experiences witnessed in the provisioning of drinking water and sanitation services in the country, as a result of bad governance that deviates from the lessons of PPOT.

Table 17: Respondents' Points of View on Reliability and Future Performance of CWC

\begin{tabular}{|c|c|c|}
\hline Parameter & Frequency & Percentage (\%) \\
\hline Able & 24 & 21.81 \\
\hline Undecided & 29 & 26.36 \\
\hline Not able & 57 & 51.81 \\
\hline Total & 110 & 100 \\
\hline
\end{tabular}

In order to assess the ability of the CWC to adequately deliver the intended services based on the views of the respondents, six individual scenarios and one aggregate case with corresponding hypotheses are developed. The first scenario is based on gender, the second scenario on marital status, the third is based on age group, the fourth on level of education, the fifth is based on profession, and the sixth is based on the area of residence, whereas the seventh scenario captures the set of all the demographic characteristics of the respondents (gender, marital status, age group, level of education, profession, and area of residence of the respondents). Contingency tables for the observed and expected frequencies of the different scenarios are constructed (Appendix) to examine the extent to which these demographic factors influence the judgment of respondents on the ability of the CWC to satisfactorily distribute the expected services in the country. The scores of the observed frequencies are used to compute the corresponding expected frequencies of the various cases. The formula for the computation of the expected frequencies is mathematically given as:

$$
E_{i}=\frac{\left(\sum_{r i}\right)\left(\sum_{c i}\right)}{N}
$$

where

$\mathrm{E}_{i}$ : Expected frequency of category $i$

$\Sigma_{r i}$ : Summation of row $i$

$\Sigma_{c i}$ : Summation of column i

$\mathrm{N}$ : Total number of observations

Then, the Chi-square $\left(\chi^{2}\right)$ statistic is applied to test the hypotheses at $5 \%$ level of significance, accordingly.

To compute the Chi-square statistic $\left(\chi^{2}\right)$, the scores of the observed and expected frequencies are combined in a single contingency table. The degree of freedom of each scenario is computed using the rows and columns of the corresponding contingency table as follows: $D f=$ (number of rows -1$) *$ (number of columns -1 ). Subsequently, the following Chi-square formula is applied in each case.

$$
\chi^{2}=\frac{\sum\left(O_{i}-E_{i}\right)^{2}}{E_{i}}
$$

The decision rule for the Chi-square $\left(\chi^{2}\right)$ statistic is generally taken with respect to the null hypothesis. Consequently, the null hypothesis is rejected if the value of the calculated Chi-square $\left(\chi_{c}^{2}\right)$ is greater than the value of the tabulated Chi-square $\left(\chi_{c}^{2}\right)$, that is, $\chi_{c}^{2}>\chi_{t}^{2}$ at a given degree of freedom $(D f)$. On the contrary, the null hypothesis is accepted if the value of the calculated Chi-square $\left(\chi_{c}^{2}\right)$ is less than or equal to the value of the tabulated 
Chi-square $\left(\chi_{t}^{2}\right)$, that is, $\chi_{c}^{2} \leq \chi_{t}^{2}$ at a given degree of freedom $(D f)$. The different scenarios can be outlined and their Chi-square $\left(\chi^{2}\right)$ statistic computed correspondingly. Yet, the alternative hypotheses which are generally opposite statements of the null hypotheses are intentionally discarded from the text to avoid redundancy. Thus, the null hypotheses of the various scenarios include:

- $\quad$ Individual Scenario 1 - Gender of respondents: Null hypothesis $-\mathrm{H}_{0}$ : Gender does not influence people's judgment on the ability of the CWC to effectively deliver the intended services in Cameroon.

- Individual Scenario 2 - Marital status of respondents: Null hypothesis $-\mathrm{H}_{0}$ : Marital status does not influence people's judgment on the ability of the CWC to adequately deliver the intended services in Cameroon.

- $\quad$ Individual Scenario 3 - Age group of respondents: Null hypothesis - $\mathrm{H}_{0}$ : Age does not influence people's judgment on the ability of the CWC to effectively deliver the intended services in Cameroon.

- $\quad$ Individual Scenario 4 - Level of education of respondents: Null hypothesis $-\mathrm{H}_{0}$ : The level of education does not influence people's judgment on the ability of the CWC to adequately deliver the intended services in Cameroon.

- $\quad$ Individual Scenario 5 - Profession of respondents: Null hypothesis - $\mathrm{H}_{0}$ : Profession does not influence people's judgment on the ability of the CWC to effectively deliver the intended services in Cameroon.

- $\quad$ Individual Scenario 6 - Area of residence of respondents: Null hypothesis $-\mathrm{H}_{0}$ : The area of residence does not influence people's judgment on the ability of the CWC to adequately deliver the intended services in Cameroon.

- $\quad$ Aggregate Scenario 7 - All demographic characteristics of respondents: Null hypothesis - $\mathrm{H}_{0}$ : Demographic characteristics do not influence people's judgment on the ability of the CWC to effectively deliver the intended services in Cameroon.

The Chi-square results for the 6 individual scenarios are recapitulated in Table 18. Under Scenario 1 (gender of the respondents), it shows that at 5\% level of significance with degree of freedom $(D f)$ equal to 2, the calculated Chi-square $\left(\chi_{c}^{2}\right)$ value of 5.056 is less than the tabulated Chi-square $\left(\chi_{t}^{2}\right)$ value of 5.991. This outcome upholds the decision rule for the acceptance of the null hypothesis $\left(\mathrm{H}_{0}\right)$. Similar conclusions are obtained under Scenario 2 (marital status with $D f=2, \chi_{c}^{2} \leq \chi_{t}^{2}$ ), Scenario 4 (level of education with $D f=4, \chi_{c}^{2} \leq \chi_{t}^{2}$ ), and Scenario 6 (residential area with $D f=2, \chi_{c}^{2} \leq \chi_{t}^{2}$ ). These results indicate that the gender, marital status, level of education, and area of residence of respondents do not have influence on the judgment of people of the ability of the CWC to effectively offer the intended services in the country. Conversely, it explains that the null hypothesis $\left(\mathrm{H}_{0}\right)$ is to be rejected under Scenario $3\left(D f=2, \chi_{c}^{2}>\chi_{t}^{2}\right)$ and Scenario $5\left(D f=6, \chi_{c}^{2}>\chi_{t}^{2}\right)$, where the calculated Chi-square $\left(\chi_{c}^{2}\right)$ values of 6.356 and 13.440 are greater than the tabulated Chi-square $\left(\chi_{t}^{2}\right)$ values of 5.991 and 12.591, respectively. With the rejection of $\mathrm{H}_{0}$, it is clear that the age and the area of residence of respondents influence their judgment of the ability of the CWC to satisfactorily distribute drinking water and sanitation services in the country. Finally, it is observed that $66.66 \%$ (4 cases) of the scenarios accepts the null hypothesis in contrast to $33.33 \%$ ( 2 cases) that rejects it (see last row of Table 18).

Table 18: Recap of Outcomes of Chi-Square Statistic on Individual Scenarios

\begin{tabular}{|c|c|c|c|c|c|c|}
\hline Parameter & Scenario 1 & Scenario 2 & Scenario 3 & Scenario 4 & Scenario 5 & Scenario 6 \\
\hline $\mathrm{H}_{0}$ & $\begin{array}{l}\text { No gender } \\
\text { influence }\end{array}$ & $\begin{array}{c}\text { No marital } \\
\text { status } \\
\text { influence }\end{array}$ & $\begin{array}{l}\text { No age } \\
\text { influence }\end{array}$ & $\begin{array}{c}\text { No level of } \\
\text { education } \\
\text { influence }\end{array}$ & $\begin{array}{l}\text { No profession } \\
\text { influence }\end{array}$ & $\begin{array}{l}\text { No residential } \\
\text { area influence }\end{array}$ \\
\hline $\mathrm{H}_{1}$ & $\begin{array}{l}\text { Gender } \\
\text { influence }\end{array}$ & $\begin{array}{c}\text { Marital } \\
\text { status } \\
\text { influence }\end{array}$ & $\begin{array}{c}\text { Age } \\
\text { influence }\end{array}$ & $\begin{array}{l}\text { Level of } \\
\text { education } \\
\text { influence }\end{array}$ & $\begin{array}{c}\text { Profession } \\
\text { influence }\end{array}$ & $\begin{array}{c}\text { Residential } \\
\text { area influence }\end{array}$ \\
\hline Control variable $(\mathrm{Cv})$ & Gender & $\begin{array}{c}\text { Marital } \\
\text { status }\end{array}$ & Age group & $\begin{array}{c}\text { Level of } \\
\text { education }\end{array}$ & Profession & $\begin{array}{c}\text { Area of } \\
\text { residence }\end{array}$ \\
\hline Category & $\begin{array}{l}\text { Male, } \\
\text { female }\end{array}$ & $\begin{array}{c}\text { Married, } \\
\text { single }\end{array}$ & $\begin{array}{c}20-40 \\
\text { years, } \\
\text { above } 40 \\
\text { years }\end{array}$ & $\begin{array}{l}\text { Primary, } \\
\text { secondary, } \\
\text { tertiary }\end{array}$ & $\begin{array}{l}\text { Student, farmer, } \\
\text { business operator, } \\
\text { civil servant }\end{array}$ & Rural, urban \\
\hline Column for $\mathrm{Cv}$ & 2 & 2 & 2 & 3 & 4 & 2 \\
\hline
\end{tabular}


Table 18 cont.

\begin{tabular}{|c|c|c|c|c|c|c|}
\hline Decision variable (Dv) & $\begin{array}{c}\text { Abe, } \\
\text { not able, } \\
\text { undecided }\end{array}$ & $\begin{array}{c}\text { Abe, } \\
\text { not able, } \\
\text { undecided }\end{array}$ & $\begin{array}{c}\text { Abe, } \\
\text { not able, } \\
\text { undecided }\end{array}$ & $\begin{array}{c}\text { Abe, } \\
\text { notable, } \\
\text { undecided }\end{array}$ & $\begin{array}{c}\text { Abe, } \\
\text { not able, } \\
\text { undecided }\end{array}$ & $\begin{array}{c}\text { Abe, } \\
\text { not able, } \\
\text { undecided }\end{array}$ \\
\hline Row for Dv & 3 & 3 & 3 & 3 & 3 & 3 \\
\hline $\begin{array}{l}\text { Degree of freedom } \\
(D f)\end{array}$ & 2 & 2 & 2 & 4 & 6 & 2 \\
\hline Significance level (\%) & 5 & 5 & 5 & 5 & 5 & 5 \\
\hline Calculated $\mathrm{X}_{\mathrm{c}}{ }^{2}$ & 5.056 & 0.902 & 6.356 & 5.822 & 13.440 & 1.094 \\
\hline Tabulated $\mathrm{X}_{\mathrm{t}}^{2}$ & 5.991 & 5.991 & 5.991 & 9.487 & 12.591 & 5.991 \\
\hline Decision rule & $\mathrm{X}_{\mathrm{c}}^{2} \leq \mathrm{X}_{\mathrm{t}}^{2}$ & $\mathrm{X}_{\mathrm{c}}^{2} \leq \mathrm{X}_{\mathrm{t}}^{2}$ & $\mathrm{X}_{\mathrm{c}}^{2}>\mathrm{X}_{\mathrm{t}}^{2}$ & $\mathrm{X}_{\mathrm{c}}^{2} \leq \mathrm{X}_{\mathrm{t}}^{2}$ & $\mathrm{X}_{\mathrm{c}}^{2}>\mathrm{X}_{\mathrm{t}}^{2}$ & $\mathrm{X}_{\mathrm{c}}^{2} \leq \mathrm{X}_{\mathrm{t}}^{2}$ \\
\hline Conclusion & Accept $\mathrm{H}_{0}$ & Accept $\mathrm{H}_{0}$ & Reject $\mathrm{H}_{0}$ & Accept $\mathrm{H}_{0}$ & Reject $\mathrm{H}_{0}$ & Accept $\mathrm{H}_{0}$ \\
\hline Total of scenarios & 6 & $100 \%$ & Accept $\mathrm{H}_{0}$ & $66.66 \%$ & Reject $\mathrm{H}_{0}$ & $33.33 \%$ \\
\hline
\end{tabular}

Under Scenario 7 (all demographic characteristics of the respondents), Table 19 explains that at $5 \%$ level of significance with degree of freedom (Df) equal to 28 , the calculated Chi-square $\left(\chi_{c}{ }^{2}\right)$ value of 32.673 is less than the tabulated Chi-square $\left(\chi_{t}^{2}\right)$ value of 41.337. This result conforms to the decision rule for the acceptance of the null hypothesis $\left(\mathrm{H}_{0}\right)$, which upholds that demographic characteristics do not influence people's judgment on the ability of the CWC to effectively deliver the intended services in Cameroon. Yet, the outcome of this model is not surprising given the following reasons. One, the model is an aggregate of all the individual scenarios. Two, out of the 6 individual scenarios, there are 4 (about 67\%) supporting the null hypothesis against 2 scenarios (about 33\%) rejecting the null hypothesis. Consequently, the effect of the high percentage (about 67\%) in support of the null hypothesis neutralized that of the low percentage (about 33\%) against the null hypothesis and biased the final outcome of the model towards the acceptance of the null hypothesis.

Table 19: Recap of Outcome of Chi-Square Statistic on Aggregate Scenario

\begin{tabular}{lc}
\hline \multicolumn{1}{c}{ Parameter } & Aggregate scenario \\
\hline $\mathrm{H}_{0}$ & No influence of demographic characteristics \\
$\mathrm{H}_{1}$ & Influence of demographic characteristics \\
Control variable & Demographic characteristics \\
Category & Male, female, married, single, 20-40 years, above 40 years, primary, secondary, tertiary, student, \\
& farmer, business operator, civil servant, rural, urban \\
Column for Cv & 15 \\
Decision variable & Abe, not able, undecided \\
Row for Dv & 3 \\
Degree of freedom $(D f)$ & 28 \\
Significance level $(\%)$ & 5 \\
Calculated $\mathrm{X}_{\mathrm{c}}{ }^{2}$ & 32.673 \\
Tabulated $\mathrm{X}_{\mathrm{t}}{ }^{2}$ & 41.337 \\
Decision rule & $\mathrm{X}_{\mathrm{c}}{ }^{2} \leq \mathrm{X}_{\mathrm{t}}^{2}$ \\
Conclusion & Accept $\mathrm{H}_{0}$ \\
\hline Source: Estimation
\end{tabular}

Source: Estimation

\section{CONCLUSION AND RECOMMENDATIONS}

A state-owned water utility company known as Société Nationale des Eaux du Cameroun (SNEC) Cameroon National Water Corporation - was established in 1967 by the Government of Cameroon to cater for the drinking water and sanitation needs of people in the country. To 2005, the company distributed drinking water through private and public tap connections, but as from 2006 public taps were discontinued due to the privatization of the corporation. As a result of privatization, customers of the company paid different water tariffs depending on their classification. Households paid 293FCFA (US\$0.586) per cubic meter $\left(\mathrm{m}^{3}\right)$ for water consumption of less than or equal to $10 \mathrm{~m}^{3}$, and 364FCFA (US\$0.728) per $\mathrm{m}^{3}$ for a consumption level above $10 \mathrm{~m}^{3}$ minimum; commercial taps were charged 293FCFA (US\$0.586) per $\mathrm{m}^{3}$ for any level of water consumption; while administrative buildings (ministries, hospitals), municipal houses (slaughter houses) and municipal taps paid 382FCFA (US\$0.764) per $\mathrm{m}^{3}$ irrespective of the volume of water used. Industries paid between 382FCFA (US\$0.764) and 322FCFA (US\$0.644) per $\mathrm{m}^{3}$ of water consumed based on a scale designed by the corporation. 
The CWC suffered from a series of technical, political, managerial as well as financial constraints, which affected its efficient functioning. These impediments contributed to a decline in its network efficiency and an increase in water rates across all categories of users, and it subjected ordinary customers to paying more taxes to acquire network connections compared to employees of the company under normal circumstances. However, the company was able to produce enough water to satisfy the demand of its subscribers in 2010 and attract funding from development partners for the development of water supply infrastructures to improve the availability of drinking water and sanitation services in the country in the near future. The company also developed proposals for the execution of water projects across the country and in some localities in dire need of additional water supplies, and to enhance the availability of drinking and sanitation services to people by 2020 . Yet, the Chi-square results for Scenario 1, Scenario 2, Scenario 4, and Scenario 6 at 5\% level of significance, indicate that the gender, marital status, level of education, and area of residence of respondents, respectively, do not have influence on the judgment of people on the ability of the CWC to effectively deliver drinking water and sanitation services in the country (accepting null hypothesis). In contrast, the Chi-square results for Scenario 3 and Scenario 5 uphold that at 5\% level of significance, the age and the area of residence of respondents, respectively, influence people's judgment about the ability of the CWC to suitably dispense drinking water and sanitation services in the country (rejecting null hypothesis). Also, it is observed that the aggregate situation (Scenario 7) advocates that at 5\% level of significance, demographic characteristics of respondents do not influence people's judgment on the ability of the CWC to effectively supply the intended services in Cameroon (accept null hypothesis), hence the need for the inclusion of additional demographic features of respondents to ascertain the rationality of this result. Finally, more than half of the population is sceptical about better services delivery by the CWC in the future.

With the perusal of the functioning devices, practices, accomplishments, constraints, prospects, and the judgments on the future performance of the CWC, it can be concluded that the abuse of available material, financial and human resources that prompted the failure of the CWC to transform into reality the vision of servicing the country with adequate water supply and sanitation services, shows that the teachings of COT were to some extent applied in the structuring of the company, whilst those of NCOT and MOT were completely ignored in its activities between 1967 and 2013. Thus, the most plausible perspective that provides a satisfactory account of the performance of the CWC, even in the urban and semi-urban centers, derives from MOT.

Despite these successes, the following points need to be taken into consideration in order to sustain positive results and advance improved living conditions of people in the country. The government needs to develop a general water supply strategy and reduce its reliance on international cooperation for the execution of capital water projects in the country. This reduced reliance requires rapid implementation of projects in anticipation of the imposition of stringent conditions for assistance from international donors vis à vis their partners, given the escalation of the financial crisis and the increase in the demand for development assistance funds from poor or developing countries on donors. It is also necessary for the government to put in place a good system of governance to check excesses and abuses of public resources by office holders at all levels of administration. This implies the prosecution of perpetrators and systematic recovery of state property from culprits. Furthermore, there is the need to widen the deregulation policy to allow for perfect competition and control of the monopoly power of the CWC in the water industry. Above all, it is imperative to educate the population and mobilize individuals towards undertaking selfreliant water development projects at community and village level. This may reduce the pressure and continual overreliance of people on the government, and improve the level of people's access to improved sources of drinking water and proper sanitation services in the country.

\section{ACKNOWLEDGEMENTS}

The authors wish to acknowledge with thanks the financial support granted by the Economic Research Southern Africa (ERSA). However, the views expressed are those of the authors and do not necessarily represent those of ERSA. The comments of our anonymous reviewers and those of the professional English language editor Carol Brammage towards improving the quality of the paper are also acknowledged. 


\section{AUTHOR INFORMATION}

Saidou Baba Oumar, School of Accounting, Economics and Finance, University of KwaZulu-Natal, Durban, South Africa. E-mail: saidoubo@gmail.com (Corresponding author)

Josue Mbonigaba, School of Accounting, Economics and Finance, University of KwaZulu-Natal, Durban, South Africa. E-mail: mbonigaba@ukzn.ac.za

\section{REFERENCES}

1. African Development Bank [AfDB] (2010). The AfDB and Cameroon 40 years of partnership. Tunis: AfDB. Retrieved 30/09/2013 from http://www.afdb.org/fileadmin/uploads/afdb/Documents/.....pdf

2. Barnard, C. I. (1938). The functions of the executive. Cambridge: Harvard University Press.

3. Blau, P. M., \& Scott, W. R. (1962). Formal organizations. San Francisco: Jossey-Bass.

4. Burns, T., \& Stalker, G. M. (1961). The management of innovation. London: Tavistock Publications.

5. $\quad$ Camerounaise des Eaux [CDE] (n.d.). Pamphlet. Greenwhich Edition.

6. $\quad$ Camerounaise des Eaux [CDE] (2008). Water bill sample 2008. Douala: CDE, S.A.

7. Cameroon Water Utilities Corporation [CAMWATER] (2007). Investir dans le secteur de la fourniture de l'eau au Cameroun. Retrieved 30/09/2013 from http//:www.camwater-cm.com/francais/agenda.php

8. Carroll, G. R., \& Hannan, M. T. (2000). The demography of corporations and industries. Princeton, NJ: Princeton University Press.

9. Cooperrider, D. L., Whitney, D., \& Stavros, J. M. (2008). Essentials of appreciative inquiry. Brunswick, $\mathrm{OH}$ : Crown Custom Publishing, Inc.

10. Docherty, J. P., Surles, R. C., \& Donovan, C. M. (2001). Organization theory. In J. A. Talbott \& R. E. Hales (eds), A textbook of administrative psychiatry. Washington, DC: American Psychiatric Publishing Inc.

11. Encyclopaedia Britannica (2010). Logone River. Retrieved 30/09/2013 from http://www.britannica.com/ EBchecked/topic/346454/Logone-River

12. Fayol, H. (1949). General and industrial management, London: Pittman.

13. Jacques, E. (1951). The changing culture of a factory, London: Tavistock Publications.

14. March, J. G. (1966). The power of power. In D. Easton (ed), Varieties of political theory (pp. 39-70). Englewood Cliffs, NJ: Prentice-Hall.

15. Maslow, A. H. (1943). A theory of human motivation. Psychological Review, 50(4), 370-396. Retrieved 23/09/2013 from http://psychclassics.yorku.ca/maslow/motivation.htm

16. Maslow, A. H. (1954). Motivation and personality. New York: Harper and Row.

17. Mayo, E. (1933). The human problems of an industrialized civilization. London: Macmillan.

18. Mbunwe, C., \& Pefok, J. D. (2009). Striking workers may turn off water supply. The Post, No 01033.

19. McGregor, D. M. (1960). The human side of enterprise. New York, London, Toronto: McGraw-Hill.

20. Merton, R. K. (1940). Bureaucratic structure and personality. Social Forces, 18(4), 560-568.

21. Meyer, J. W., \& Rowan, B. (1977). Institutionalized organizations: Formal structure as myth and ceremony. American Journal of Sociology, 83, 340-363.

22. Mintzberg, H. (1992). Structure in fives: Designing effective organizations. Upper Saddle River, NJ: Prentice Hall.

23. Molua, E. L., \& Lambi, C. M. (2006). Climate, hydrology and water resources in Cameroon. (Discussion Paper No.33). Special Series on Climate Change and Agriculture in Africa, University of Pretoria, Pretoria: Centre for Environmental Economics and Policy in Africa [CEEPA]. Retrieved 30/08/2013 from http://www.ceepa.co.za/docs/CDPNo33.pdf

24. National Archives, Buea, Cameroon [NABC], File Rd [1991]1. Water supplies - SNEC 1991 (pp. 76-101, 233-237, 379-473, 491-529). Buea: NABC.

25. National Institute of Statistics [NIS] (2006). Cameroon statistical year book 2006. Yaoundé: NIS.

26. Neba, A. S. (1999). Modern geography of the Republic of Cameroon (3 ed.). Bamenda: Neba Publishers.

27. Ngnikam, E. (2007). Le DSRP est-il une réponse pour améliorer l'accès à l'eau potable des populations pauvres dans les PED? Paper presented at Development Research Forum, University of Montréal: Canada, January. Retrieved 30/09/2013 from http://www.cerium.ca/IMG/pdf/Communication_No1.pdf 
28. Ouchi, W. G. (1981). Theory Z: How American business can meet the Japanese challenge. Reading, MA: Addison-Wesley.

29. Oumar, S. B. (2012). The management of water resource in Cameroon. Saarbrücken, Germany: Lambert Academic Publishing GmbH and Co. K.G.

30. Pfeffer, J. (1994). Managing with power: Politics and influence in organizations. Boston: Harvard Business School Press.

31. Pfeffer, J., \& Salancik, G. R. (2003). The external control of organizations: A resource dependence perspective. Stanford, CA: Stanford University Press.

32. Pibasso, A. M. (2008). La collaboration Maroc-Cameroun améliore l'offre en eau potable. Les Afriques, No.33. Retrieved 30/09/2013 from http://www.lesafriques.com/politique-economie/la-collaboration-maroccameroun-ameliore-1-offre-en-eau-pot-2.html?Itemid=308?articleid=7027

33. Republic of Cameroon [RC] (2007a). Lettre de politique sectorielle de l'hydraulique urbaine. Retrieved 30/09/2013 from http://www.pseau.org/outils/ouvrages/minee_...pdf

34. Republic of Cameroon [RC] (2007b). Contrat-plan entre la République du Cameroun et la Cameroon Water Utilities Corporation. Retrieved 30/09/13 from http:www.era-cameroun.com/download.php?

35. Schein, E. H. (2004). Organizational culture and leadership (3 ed.). San Francisco: Jossey-Bass.

36. Selznick, P. (1948). Foundations of the theory of organization. American Sociological Review, 13(1), 2535. Retrieved 23/09/2013 from http://links.jstor.org/sici?sici=0003-1224\%28194802\%2913\%3A1\%3C 25

37. Smith, A. (1776). An inquiry into the nature and causes of the wealth of nations. Reprinted in 1976, United Kingdom: Clarendon Press.

38. Walker, A. H., \& Lorsch, J. W. (1968).“Organizational choice: Product versus function. Harvard Business Review, November-December.

39. Walkup, M. (1997). Policy dysfunction in humanitarian organizations: The role of coping strategies, institutions, and organizational culture. Journal of Refugees Studies, 10(1), 37-60.

40. Weber, M. (1922). Bureaucracy. In H. H. Gerth \& C. W. Mills (1948), From Max Weber: Essays in sociology. London: Routledge and Kegan Paul.

41. Weber, M. (1947). The theory of social and economic organization (first published 1924). Glencoe, Illinois: The Free Press.

42. Wiener, N. (1948). Cybernetics or control and communication in the animal and the machine. New York: John Wiley and Sons, Inc.

43. Williamson, O. E. (1975). Markets and hierarchies, analysis and antitrust implications: A study on the economics of internal organization. New York: The Free Press.

44. World Bank (2010). Background of Cameroon's privatisation programme. Retrieved 30/09/2013 from http://www.fdi.net/documernts/WorldBank/databases/plink/cam/pes.htm

45. World Bank (2013). Atlas of global development: A visual guide to the world's greatest challenges (4 ed.) Glasgow: Collins Bartholomow. Retrieved 30/09/2013 from https://openknowledge.worldbank.org/handle/10986/13089 


\section{Appendix: Computation Tables of Chi-Square Statistic of Scenarios}

Table A: Computation of Chi-Square Statistic with Reference to Gender of Respondents

\begin{tabular}{|c|c|c|c|c|}
\hline $\mathrm{O}_{\mathrm{i}}$ & $\mathbf{E}_{\mathrm{i}}$ & $\left(\mathrm{O}_{\mathrm{i}}-\mathrm{E}_{\mathrm{i}}\right)$ & $\left(O_{i}-E_{i}\right)^{2}$ & $\left(O_{i}-E_{i}\right)^{2} \div E_{i}$ \\
\hline 14 & 13.96 & 0.04 & 0.0016 & 0.000115 \\
\hline 12 & 16.87 & -4.87 & 23.7169 & 1.405862 \\
\hline 38 & 33.16 & 4.84 & 23.4256 & 0.706441 \\
\hline 10 & 10.03 & -0.03 & 0.0009 & $8.97 \mathrm{E}-05$ \\
\hline 17 & 12.12 & 4.88 & 23.8144 & 1.964884 \\
\hline 19 & 23.83 & -4.83 & 23.3289 & 0.978972 \\
\hline- & - & - & Total & 5.056364 \\
\hline
\end{tabular}

Table B: Computation of Chi-Square Statistic with Regard to Marital Status of Respondents

\begin{tabular}{|c|c|c|c|c|}
\hline $\mathbf{O}_{\mathrm{i}}$ & $\mathbf{E}_{\mathrm{i}}$ & $\left(\mathbf{O}_{\mathrm{i}}-\mathbf{E}_{\mathrm{i}}\right)$ & $\left(O_{i}-E_{i}\right)^{2}$ & $\left(O_{i}-E_{i}\right)^{2} \div E_{i}$ \\
\hline 11 & 12.43 & -1.43 & 2.0449 & 0.164513 \\
\hline 17 & 15.02 & 1.98 & 3.9204 & 0.261012 \\
\hline 29 & 29.53 & -0.53 & 0.2809 & 0.009512 \\
\hline 13 & 11.56 & 1.44 & 2.0736 & 0.179377 \\
\hline 12 & 13.97 & -1.97 & 3.8809 & 0.277802 \\
\hline 28 & 27.46 & 0.54 & 0.2916 & 0.010619 \\
\hline- & - & - & Total & 0.902835 \\
\hline
\end{tabular}

Table C: Computation of Chi-Square Statistic with Connection to Age Group of Respondents

\begin{tabular}{|c|c|c|c|c|}
\hline$\overline{\mathbf{O}_{\mathrm{i}}}$ & $\mathbf{E}_{\mathrm{i}}$ & $\left(\mathbf{O}_{\mathrm{i}}-\mathrm{E}_{\mathrm{i}}\right)$ & $\left(O_{i}-E_{i}\right)^{2}$ & $\left(\mathbf{O}_{\mathrm{i}}-\mathrm{E}_{\mathrm{i}}\right)^{2} \div \mathrm{E}_{\mathrm{i}}$ \\
\hline 23 & 21.16 & 1.84 & 3.3856 & 0.16 \\
\hline 28 & 25.57 & 2.43 & 5.9049 & 0.230931 \\
\hline 46 & 50.26 & -4.26 & 18.1476 & 0.361074 \\
\hline 1 & 2.83 & -1.83 & 3.3489 & 1.183357 \\
\hline 1 & 3.42 & -2.42 & 5.8564 & 1.712398 \\
\hline 11 & 6.73 & 4.27 & 18.2329 & 2.709198 \\
\hline - & - & - & Total & 6.356958 \\
\hline
\end{tabular}

Table D: Computation of Chi-Square Statistic with Respect to Level of Education of Respondents

\begin{tabular}{|c|c|c|c|c|}
\hline$\overline{\mathbf{O}_{\mathrm{i}}}$ & $\mathbf{E}_{\mathrm{i}}$ & $\left(\mathbf{O}_{i}-E_{i}\right)$ & $\left(\mathbf{O}_{\mathrm{i}}-\mathbf{E}_{\mathrm{i}}\right)^{2}$ & $\left(\mathbf{O}_{i}-E_{i}\right)^{2} \div E_{i}$ \\
\hline 3 & 5.45 & -2.45 & 6.0025 & 1.101376 \\
\hline 10 & 6.59 & 3.41 & 11.6281 & 1.764507 \\
\hline 12 & 12.95 & -0.95 & 0.9025 & 0.069691 \\
\hline 6 & 7.63 & -1.63 & 2.6569 & 0.348218 \\
\hline 9 & 9.22 & -0.22 & 0.0484 & 0.005249 \\
\hline 20 & 18.13 & 1.87 & 3.4969 & 0.192879 \\
\hline 15 & 10.90 & 4.1 & 16.81 & 1.542202 \\
\hline 10 & 13.18 & -3.18 & 10.1124 & 0.767253 \\
\hline 25 & 25.90 & -0.9 & 0.81 & 0.031274 \\
\hline - & - & - & Total & 5.822649 \\
\hline
\end{tabular}

Table E: Computation of Chi-Square Statistic in Association with Profession of Respondents

\begin{tabular}{|c|c|c|c|c|}
\hline $\mathbf{O}_{\mathbf{i}}$ & $\mathbf{E}_{\mathrm{i}}$ & $\left(\mathbf{O}_{i}-E_{i}\right)$ & $\left(\mathbf{O}_{\mathrm{i}}-\mathrm{E}_{\mathrm{i}}\right)^{2}$ & $\left(\mathbf{O}_{\mathrm{i}}-\mathrm{E}_{\mathrm{i}}\right)^{2} \div \mathrm{E}_{\mathrm{i}}$ \\
\hline 12 & 7.41 & 4.59 & 21.0681 & 2.843198 \\
\hline 6 & 8.96 & -2.96 & 8.7616 & 0.977857 \\
\hline 16 & 17.61 & -1.61 & 2.5921 & 0.147195 \\
\hline 0 & 4.36 & -4.36 & 19.0096 & 4.36 \\
\hline 5 & 5.27 & -0.27 & 0.0729 & 0.013833 \\
\hline 15 & 10.36 & 4.64 & 21.5296 & 2.078147 \\
\hline 3 & 5.01 & -2.01 & 4.0401 & 0.806407 \\
\hline 9 & 6.06 & 2.94 & 8.6436 & 1.426337 \\
\hline 11 & 11.91 & -0.91 & 0.8281 & 0.06953 \\
\hline 9 & 7.20 & 1.8 & 3.24 & 0.45 \\
\hline 9 & 8.70 & 0.3 & 0.09 & 0.010345 \\
\hline 15 & 17.10 & -2.1 & 4.41 & 0.257895 \\
\hline - & - & - & Total & 13.44074 \\
\hline
\end{tabular}


Table F: Computation of Chi-Square Statistic with Relation to Residential Area of Respondents

\begin{tabular}{|c|c|c|c|c|}
\hline $\mathbf{O}_{\mathrm{i}}$ & $\mathbf{E}_{\mathrm{i}}$ & $\left(\mathbf{O}_{\mathrm{i}}-\mathbf{E}_{\mathrm{i}}\right)$ & $\left(O_{i}-E_{i}\right)^{2}$ & $\left(O_{i}-E_{i}\right)^{2} \div E_{i}$ \\
\hline 14 & 12.65 & 1.35 & 1.8225 & 0.144071 \\
\hline 13 & 15.29 & -2.29 & 5.2441 & 0.342976 \\
\hline 31 & 30.05 & 0.95 & 0.9025 & 0.030033 \\
\hline 10 & 11.34 & -1.34 & 1.7956 & 0.158342 \\
\hline 16 & 13.70 & 2.3 & 5.29 & 0.386131 \\
\hline 26 & 26.94 & -0.94 & 0.8836 & 0.032799 \\
\hline- & - & - & Total & 1.094352 \\
\hline
\end{tabular}

Table G: Computation of Aggregate Chi-Square Statistic of all Demographic Characteristics of Respondents

\begin{tabular}{|c|c|c|c|c|}
\hline $\mathbf{O}_{\mathrm{i}}$ & $\mathbf{E}_{\mathbf{i}}$ & $\left(\mathbf{O}_{\mathrm{i}}-\mathrm{E}_{\mathrm{i}}\right)$ & $\left(\mathbf{O}_{\mathrm{i}}-\mathrm{E}_{\mathrm{i}}\right)^{2}$ & $\left(O_{i}-E_{i}\right)^{2} \div E_{i}$ \\
\hline 14 & 13.96 & 0.04 & 0.0016 & 0.000115 \\
\hline 12 & 16.87 & -4.87 & 23.7169 & 1.405862 \\
\hline 38 & 33.16 & 4.84 & 23.4256 & 0.706441 \\
\hline 10 & 10.03 & -0.03 & 0.0009 & 8.97E-05 \\
\hline 17 & 12.12 & 4.88 & 23.8144 & 1.964884 \\
\hline 19 & 23.83 & -4.83 & 23.3289 & 0.978972 \\
\hline 11 & 12.43 & -1.43 & 2.0449 & 0.164513 \\
\hline 17 & 15.02 & 1.98 & 3.9204 & 0.261012 \\
\hline 29 & 29.53 & -0.53 & 0.2809 & 0.009512 \\
\hline 13 & 11.56 & 1.44 & 2.0736 & 0.179377 \\
\hline 12 & 13.97 & -1.97 & 3.8809 & 0.277802 \\
\hline 28 & 27.46 & 0.54 & 0.2916 & 0.010619 \\
\hline 23 & 21.16 & 1.84 & 3.3856 & 0.16 \\
\hline 28 & 25.57 & 2.43 & 5.9049 & 0.230931 \\
\hline 46 & 50.26 & -4.26 & 18.1476 & 0.361074 \\
\hline 1 & 2.83 & -1.83 & 3.3489 & 1.183357 \\
\hline 1 & 3.42 & -2.42 & 5.8564 & 1.712398 \\
\hline 11 & 6.73 & 4.27 & 18.2329 & 2.709198 \\
\hline 3 & 5.45 & -2.45 & 6.0025 & 1.101376 \\
\hline 10 & 6.59 & 3.41 & 11.6281 & 1.764507 \\
\hline 12 & 12.95 & -0.95 & 0.9025 & 0.069691 \\
\hline 6 & 7.63 & -1.63 & 2.6569 & 0.348218 \\
\hline 9 & 9.22 & -0.22 & 0.0484 & 0.005249 \\
\hline 20 & 18.13 & 1.87 & 3.4969 & 0.192879 \\
\hline 15 & 10.90 & 4.1 & 16.81 & 1.542202 \\
\hline 10 & 13.18 & -3.18 & 10.1124 & 0.767253 \\
\hline 25 & 25.90 & -0.9 & 0.81 & 0.031274 \\
\hline 12 & 7.41 & 4.59 & 21.0681 & 2.843198 \\
\hline 6 & 8.96 & -2.96 & 8.7616 & 0.977857 \\
\hline 16 & 17.61 & -1.61 & 2.5921 & 0.147195 \\
\hline 0 & 4.36 & -4.36 & 19.0096 & 4.36 \\
\hline 5 & 5.27 & -0.27 & 0.0729 & 0.013833 \\
\hline 15 & 10.36 & 4.64 & 21.5296 & 2.078147 \\
\hline 3 & 5.01 & -2.01 & 4.0401 & 0.806407 \\
\hline 9 & 6.06 & 2.94 & 8.6436 & 1.426337 \\
\hline 11 & 11.91 & -0.91 & 0.8281 & 0.06953 \\
\hline 9 & 7.20 & 1.8 & 3.24 & 0.45 \\
\hline 9 & 8.70 & 0.3 & 0.09 & 0.010345 \\
\hline 15 & 17.10 & -2.1 & 4.41 & 0.257895 \\
\hline 14 & 12.65 & 1.35 & 1.8225 & 0.144071 \\
\hline 13 & 15.29 & -2.29 & 5.2441 & 0.342976 \\
\hline 31 & 30.05 & 0.95 & 0.9025 & 0.030033 \\
\hline 10 & 11.34 & -1.34 & 1.7956 & 0.158342 \\
\hline 16 & 13.70 & 2.3 & 5.29 & 0.386131 \\
\hline 26 & 26.94 & -0.94 & 0.8836 & 0.032799 \\
\hline- & - & - & Total & 32.6739017 \\
\hline
\end{tabular}


NOTES 